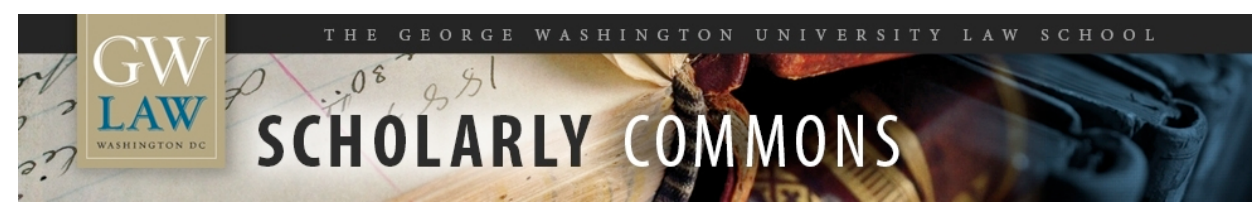

GW Law Faculty Publications \& Other Works

Faculty Scholarship

2013

\title{
Regulatory Design in Context
}

Robert L. Glicksman

George Washington University Law School, rglicksman@law.gwu.edu

David L. Markell

Follow this and additional works at: https://scholarship.law.gwu.edu/faculty_publications

Part of the Law Commons

\section{Recommended Citation}

Glicksman, Robert L. and Markell, David L., "Regulatory Design in Context" (2013). GW Law Faculty Publications \& Other Works. 1039.

https://scholarship.law.gwu.edu/faculty_publications/1039

This Article is brought to you for free and open access by the Faculty Scholarship at Scholarly Commons. It has been accepted for inclusion in GW Law Faculty Publications \& Other Works by an authorized administrator of Scholarly Commons. For more information, please contact spagel@law.gwu.edu. 


\title{
DRAFT - PLEASE DO NOT CITE OR DISTRIBUTE WITHOUT PERMISSION OF AUTHORS
}

\author{
Regulatory Design in Context \\ David L. Markell* and Robert L. Glicksman ${ }^{* *}$
}

\begin{abstract}
This paper offers what we hope is a constructive contribution to the debate about whether legal scholarship is (in)sufficiently tethered to the real world. To the extent there is a disconnect, we believe neither scholars nor the real world of governance are necessarily at fault. Instead, the disconnect stems from a failure to forge connections between theoretical constructs in the academic literature and their applicability to real world conditions. In part, this article is an effort to make such connections through close attention to context in regulatory design.
\end{abstract}

In an insightful recent article, Agencies as Litigation Gatekeepers, Professor David Freeman Engstrom offers a conceptual framework for reorienting the literature on regulatory enforcement by shifting the focus from a choice between public and private enforcement to analysis of how best to coordinate multiple, overlapping, and interdependent public and private enforcers by vesting in federal agencies "gatekeeping authority" over private enforcement lawsuits. Professor Engstrom discusses theoretical concerns about allowing private actors to bring enforcement cases, and the challenges present in designing welfare-maximizing gatekeeping regimes. Professor Engstrom suggests design options for rationalizing public and private enforcement lawsuits through a public "gatekeeping" scheme that range from empowering agencies to be "extremely interventionist" gatekeepers to restricting them to a much more limited role in shaping private enforcement efforts.

Our article evaluates and builds on Professor Engstrom's important effort to rationalize government and private enforcement of regulatory norms by considering his effort in the context of challenges facing government enforcers in the real world, and the Environmental Protection Agency (EPA) in particular. We suggest that agencies such as EPA confront at least five design challenges in developing pragmatic enforcement strategies: the inter-related character of different components of the regulatory process; the hybrid character of contemporary governance efforts; the importance of confronting "reality" in the form of past performance and future challenges and opportunities; the dynamic character of contemporary governance and responses to it; and the salience of possible design changes, which suggests the need to prioritize design improvements. Our view is that pursuing sensible regulatory design, including mechanisms of the sort Professor Engstrom proposes, requires a sophisticated understanding of the regulatory landscape and that our conceptual framework provides a useful typology for developing such an understanding. In short, our article attempts a synthesis of Professor Engstrom's valuable insights about the value of optimizing regulatory enforcement initiatives with our own conception of the manner in which the regulatory state operates in order to provide a contextually-based, pragmatic framework for optimizing regulatory design to promote compliance with regulatory norms.

\footnotetext{
* Stephen M. Goldstein Professor of Law, Florida State University College of Law.

** J.B. \& Maurice C. Shapiro Professor of Environmental Law, George Washington University Law School. The authors thank for reviewing drafts of this Essay and for valuable research assistance.
} 


\section{DRAFT - PLEASE DO NOT CITE OR DISTRIBUTE WITHOUT PERMISSION OF AUTHORS}

$\underline{\text { Introduction }}$

The search for optimal regulatory design is a long-standing one with no clear end in sight. A recent entry in the legal academic literature, Professor David Freeman Engstrom's Agencies as Litigation Gatekeepers, ${ }^{1}$ refers to the scholarly debate surrounding optimal regulatory design while focusing primarily on the "institutional design challenge" raised by regulatory enforcement. ${ }^{2}$ More specifically, Professor Engstrom calls for a reorientation of the literature from focusing on a choice between public and private enforcement to instead focusing on how best to coordinate multiple, overlapping, and interdependent public and private enforcers by vesting in federal agencies "gatekeeping authority" over private enforcement lawsuits. ${ }^{3}$

Acknowledging the importance of context in regulatory design, ${ }^{4}$ Professor Engstrom discusses theoretical concerns about allowing private actors to bring enforcement cases, such as overzealousness, challenges in coordination between private and public enforcers, and risks to legislative fidelity. ${ }^{5} \mathrm{He}$ also addresses the challenges that "bureaucratic behavioral pathologies" such as possible agency capture, agency self-aggrandizement, agencies' predilections for overly cautious behavior, and the influence of careerist incentives of agency personal present in designing gatekeeping regimes that will prove to be welfare-maximizing. ${ }^{6}$ Professor Engstrom suggests a minimum of five design dimensions for rationalizing public and private enforcement lawsuits through establishment of a public "gatekeeping" scheme to set parameters for private enforcement, ranging from empowering agencies to be "extremely interventionist" gatekeepers to playing a much more limited role in shaping private enforcement efforts. ${ }^{7}$

This Essay evaluates and builds on Professor Engstrom's important theoretical effort to rationalize government and private enforcement of regulatory norms by considering his effort in the context of challenges facing government enforcers in the real world. ${ }^{8}$ It engages Professor

\footnotetext{
${ }^{1}$ David Freeman Engstrom, Agencies as Litigation Gatekeepers, 123 YALE L.J. (forthcoming 2013), available at http://papers.ssrn.com/sol3/papers.cfm?abstract_id=2290843.

${ }^{2}$ Id. at __ [ms at 3,9].

${ }^{3} I d$. at _ [ms at $\left.4-5\right]$.

${ }^{4} I d$. at _ [ms at 26] (noting, for example, that "an important theme ... is that optimal gatekeeper design is likely to be highly contextual and grounded in the realities of a given regulatory regime." He also notes that "any assessment of the institutional competence and capacity of agencies to perform gatekeeper tasks will necessarily be comparative.... The question is whether agencies can ... make better judgments [of competing modes of enforcement in a complex regulatory regime] . . . or do so more quickly or cheaply, than other institutional actors." $I d$. at 31 .

${ }^{5} I d$. at _ _ [ms at 10-17].

${ }^{6}$ Id. at ___ [ms at 39-41]

${ }^{7}$ As he puts it, the typology is "designed to be a useful tool, as regulatory designers who desire relatively greater or lesser agency control over private litigation efforts can simply move up or down the taxonomic ladder." Id. at 26.

8 This paper offers what we hope is a constructive contribution to the debate about whether legal scholarship is (in)sufficiently tethered to the real world by attempting a synthesis of Professor Engstrom's valuable theoretical insights about the value of optimizing regulatory enforcement initiatives with our own conception of the manner in which the regulatory state operates. Our goal is to provide a contextually-based, pragmatic framework for optimizing regulatory design to promote compliance with regulatory norms. For differing views about the value of legal scholarship in terms of the resolution of real-world challenges, see, e.g., Harry T. Edwards, The Growing Disjunction Between Legal Education and the Legal Profession, 91 MicH. L. REv. 34, 36 (1992) (endorsing scholarship that reflects "a healthy balance of theory and doctrine"); Catherine A. MacKinnon, Engaged Scholarship as Method and Vocation, 22 YALE J.L. \& FEMINISM 193, 204 (2010) (urging scholarship that "is both grounded and
} 


\section{DRAFT - PLEASE DO NOT CITE OR DISTRIBUTE WITHOUT PERMISSION OF AUTHORS}

Engstrom's attempt to optimize regulatory design of agency gatekeeping of private enforcement by highlighting, and elaborating on, five key elements of a conceptual framework that we believe will contribute to improved regulatory design, including but not limited to efforts to enhance regulatory compliance. While Professor Engstrom addresses the experiences of a broad range of agencies in his search for optimal design, our proposed framework is based on the experience of a single agency, the federal Environmental Protection Agency (EPA). ${ }^{9}$

First, efforts to advance optimal regulatory design need to consider the fundamentally inter-related character of different aspects of the regulatory process. In the world of environmental regulation, for example, a Congressional Research Service (CRS) report notes that "[c]ompliance with pollution control laws is addressed through a continuum of response mechanisms, ranging from compliance assistance to administrative and civil enforcement, to the stronger criminal enforcement." 10 We believe that the continuum is even broader than the CRS report suggests, reaching at least as far back as the initial adoption of regulatory requirements. Further, these response mechanisms are inter-related rather than independent. As a result, a search for optimal regulatory design, even if limited to the design of discrete parts of the process such as Professor Engstrom's focus on gatekeeping strategies for formal enforcement, ${ }^{11}$ must consider the full range of activities that comprise the regulatory process as well as the results that process produces. The taxonomy we offer below highlights key features of the regulatory process and types of interconnections that require attention as part of optimal regulatory design efforts. $^{12}$

theoretical, actively involved in the world of its subject matter, and for that reason, able to think about it in fresh ways").

${ }^{9}$ We are most familiar with EPA and hence have focused on regulatory design issues based on that agency's compliance promotion strategies. The search for optimal regulatory design is likely to be highly dependent on context, as Engstrom and others have noted. See Stephen B. Burbank, Sean Farhang, \& Herbert M. Kritzer, Private Enforcement, 17 LEWIS \& CLARK L. REV. 637, 640, 662, 685 (2013); Alejandro E. Camacho \& Robert L. Glicksman, Functional Government in 3-D: A Framework for Evaluating Allocations of Government Authority, 51 HARV. J. ON LEGIS. __ (forthcoming 2014) (discussing the multiple dimensions along which regulatory authority may be allocated and the potential value of allocating authority along functional lines). As others have noted, this context dependency holds true of the design of enforcement regimes. See, e.g., J. Maria Glover, The Structural Role of Private Enforcement Mechanisms in Public Law, 53 WM. \& MARY L. REV. 1137, 1145 (2012) (discussing a "unified approach to the design of private enforcement mechanisms better tailored to the exigencies of particular regulatory regimes").

${ }^{10}$ Robert Esworthy, Federal Pollution Control Laws: How Are They Enforced?, Congressional Research Service Report 19 (June 18, 2013) [hereinafter Esworthy, How Are They Enforced?]; U.S. EPA Office of Compliance, Guide to Calculating Environmental Benefits from EPA Enforcement Cases - FY 2012 Update vii, I-6 (January 10, 2012 Final) (providing guidance about how to collect information on the "results and environmental benefits" from concluded federal enforcement cases).

${ }^{11}$ Professor Engstrom discusses different criteria by which agencies might exercise their gatekeeping functions, including allowing private suits based on the probability that the private action will prevail in court or on a much broader set of considerations such as the implications of allowing private actions for legislative fidelity. Engstrom, supra note 1, at _ _ [ms at 35]. Our argument here focuses on gatekeeping with the latter perspective as our backdrop. Professor Engstrom acknowledges that the line between enforcement litigation generally and other aspects of regulation is becoming "increasingly blurred." $I d$. at __ [ $\mathrm{ms}$ at 6].

${ }^{12}$ See infra Part I. These interconnections work in both directions, as design and implementation of other stages of the regulatory process influence optimal design and implementation of the gatekeeping element that Professor Engstrom highlights and vice versa. 


\section{DRAFT - PLEASE DO NOT CITE OR DISTRIBUTE WITHOUT PERMISSION OF AUTHORS}

Second, efforts to achieve optimal regulatory design should be mindful of the hybrid character of contemporary governance. Governance is much more than simply the actions of government actors, as Engstrom's analysis of the interaction of public and private enforcement reflects. Again, however, the range of actors is broader than agency and private enforcers, and governance often benefits (or suffers) from the actions of these multiple stakeholders. ${ }^{13}$ As Environmental Law Institute President John C. Cruden has put it, most of those in Cruden's generation "in the environmental world grew up on public law."14 As a result, it is especially important in the search for optimal regulatory design not only to acknowledge the reality, but also to assess both the promise and perils of different variations of hybrid governance (or, as Professor Engstrom characterizes it, "the pluralistic regulatory landscape"). ${ }^{15}$ Engstrom also refers to the "complex ecologies of enforcement" within which multiple public and private enforcers operate and with which they interact. ${ }^{16}$ As others have amply demonstrated, these "complex ecologies" extend beyond ex post enforcement actions by either public or private actors. ${ }^{17}$ One key insight from this central feature of contemporary governance is that efforts to

The search for optimal regulatory design should consider informal controls as well and the relationship between regulatory efforts and other efforts to induce desirable environmental behavior. See, e.g., Sally S. Simpson et al., An Empirical Assessment of Corporate Environmental Crime-Control Strategies, 101 J. CRIM. L. \& CRIMINOLOGY 231. 265 (2013) (discussing a "symbiosis between formal and informal controls" and arguing that "[f]ormal sanctions do not work in isolation"). It also should consider inter-governmental relationships. Professor Engstrom focuses almost exclusively on ex post enforcement against regulated parties after they have (allegedly) violated legal requirements, giving almost no attention to coordination between federal and state actors in that effort. He does not spend much time on the challenge of rationalizing government enforcement, independent of private actors. For assessments of this challenge, see, e.g., David L. Markell, The Role of Deterrence-Based Enforcement in a "Reinvented" State/Federal Relationship: The Divide Between Theory and Reality, 24 HARV. ENVTL. L. REV. 1 (2000) [hereinafter Markell, Deterrence-Based Enforcement]. For another recent example of analysis of regulatory design of public enforcement mechanisms, see Margaret H. Lemos \& Max Minzner, For-Profit Public Enforcement, 127 HARV. L. REV. (forthcoming Jan. 2014), available at

http://papers.ssrn.com/sol3/papers.cfm?abstract_id=2296087 (focusing on how financial incentives can spur public enforcement).

${ }^{13}$ See, e.g., Peter Grabosky, Beyond Responsive Regulation: The Expanding Role of Non-State Actors in the Regulatory Process, 7 REGULATION \& GOVERNANCE 114, 118 (2013) (suggesting that advances in technology may engender "wiki-regulation"); THE TOOLS OF GOVERnMENT: A GuIDE TO THE NEW GOVERnANCE (Lester M. Salamon ed., Oxford Univ. Press 2002) [hereinafter ToOLS OF GovERNMENT]; Jody Freeman, The Private Role in Public Governance, 75 N.Y.U. L. REV. 543 (2000). Engstrom identifies some of the perils of reliance on private enforcement, as have others. See, e.g., Grabosky, supra, at 119 (noting concerns about private regulatory failure, the potential for private voices to be ignored, lack of accountability, and private overzealousness when acting in a regulatory capacity). As Grabosky colorfully puts it, the sword of citizen participation is two-edged. One would not wish to see the advent of wiki witch hunts. Id. at __. See also Timur Kuran \& Cass R. Sunstein, Availability Cascades and Risk Regulation, 51 STAN. L. REV. 683 (1999).

${ }^{14}$ John C. Cruden, The Brave New World of Private Governance, 30 ENVTL. F. 60, 60 (2013).

${ }^{15}$ Engstrom, supra note 1, at __ [ms at 9].

${ }^{16} \mathrm{Id}$.

${ }^{17}$ According to Professor Delmas, "the inadequacy of governments to resolve some environmental issues has generated the search for alternative governance mechanisms." GOVERNANCE FOR THE ENVIRONMENT: NEW Perspectives 223 (Magali A. Delmas \& Oran R. Young eds., Cambridge Univ. Press 2009) [hereinafter GOVERNANCE FOR THE ENVIRONMENT]. There are enormous varieties of governance, including self-regulation in the form of Responsible Care, see American Chemistry Council, Responsible Care, http://responsiblecare.americanchemistry.com/?gclid=CN6klbiLkroCFQ-g4AodLVQAIQ, supply chain influences, certification schemes, and others. See ISO 14001: ENVIRONMENTAL MANAGEMENT SYSTEMS (2004); Cruden, supra note __ (discussing private certification standards for private forests); Lesley K. McAllister, Regulation by ThirdParty Verification, 53 B.C. L. REV. 1, 14 (2012). In Grabosky’s terms, regulatory instruments may entail elements 


\section{DRAFT - PLEASE DO NOT CITE OR DISTRIBUTE WITHOUT PERMISSION OF AUTHORS}

enhance compliance should take into account how best to engage all stakeholders at different stages of the regulatory process, not just public officials and NGO litigants during the ex post stage of enforcement litigation. ${ }^{18}$

A third, different type of contextual feature that is particularly relevant to the question of optimal design of regulatory enforcement structures, and of agency authority to engage in gatekeeping of private enforcement initiatives, is what we term the "reality check" contextual feature. In revisiting regulatory design it is critical to assess the agency's (here EPA's) actual performance in conducting enforcement, the challenges the agency faces, and opportunities to improve performance by altering regulatory features or practices.

The degree of dynamism is the fourth feature of regulation that we suggest regulatory designers should consider. This is not a feature that receives much attention in Agencies as Litigation Gatekeepers, but we believe it deserves "front-and-center" status. Optimal regulatory design requires an understanding of the extent to which key features of regulation are likely to be static or dynamic over time. This feature differs from the third feature in that it focuses not on whether existing regulatory practices have worked as anticipated even if the environment in which those practices occur has remained static, but on whether the environment itself has shifted in ways that affect regulatory goals. For example, changes in agency personnel and financial resources, improvements in monitoring technology, and the capacity of regulated parties and NGOs to participate in regulatory implementation are among a litany of factors that affect EPA's capacity for effective governance. ${ }^{19}$ EPA is relying heavily on new monitoring tools and data management capabilities to address compliance challenges, as we discuss below. ${ }^{20}$ Thus, another contextual feature highlighted in this Essay as an indispensable component of regulatory design is awareness of the likelihood that capabilities and interests of different key actors throughout the entire regulatory enterprise will change over time.

\footnotetext{
of state, self-regulatory, and third-party activity. Grabosky, supra note__, at 120. See also id. at 118 (noting the "enormous potential for digital technology to enhance the regulatory capacity of ordinary citizens," including the potential for citizens to "assist in labor-intensive investigation of non-compliance"). While the scholarship on such hybrid forms of governance is growing rapidly, Professor Delmas suggests that "the research on environmental governance without government, or between government and other actors, is only just emerging." For discussion of some of the challenges posed by hybrid governance challenges in the law review literature, see David L. Markell, "Slack" in the Administrative State and its Implications for Governance: The Issue of Accountability, 84 OR. L. REV. 1 (2005) [hereinafter Markell, Slack]; Clifford Rechtschaffen \& David L. Markell, Improving State Environmental Enforcement Performance Through Enhanced Government Accountability and Other Strategies, 33 ENVTL. L.REP.. 10559 (2003).

${ }^{18}$ For one effort to identify key actors in the implementation and enforcement of environmental laws, see Esworthy, How Are They Enforced?, supra note _, at 1 (listing federal, state, tribal, and local governments, regulated parties, courts, interest groups, and the general public as relevant stakeholders).

${ }^{19}$ There is a rich literature that investigates the ways in which regulated parties are motivated by a variety of factors, including utilitarian considerations as well as cultural norms and habits, and it is worthwhile to consider all of these sources of motivation in regulatory design. See, e.g.,GoVERNANCE FOR THE ENVIRONMENT, supra note _, at 9, 223; Michael P. Vandenbergh, Amanda P. Carrico \& Lisa Schultz Bressman, Regulation in the Behavioral Era, 95 MinN. L. REV. 715 (2011); Michael P. Vandenbergh, Order Without Social Norms: How Personal Norm Activation Can Protect the Environment, 99 Nw. U. L. REV. 1101(2005); Michael P. Vandenbergh, Beyond Elegance: A Testable Typology of Social Norms in Corporate Environmental Compliance, 22 STAN. ENVTL. L.J. 55 (2003); Neil Gunningham, Robert A. Kagan \&Dorothy Thornton, Social License and Environmental Protection: Why Businesses Go Beyond Compliance, 29 LAW \& SoC. INQUIRY 307 (2004).

${ }^{20}$ See infra Part III.
} 


\section{DRAFT - PLEASE DO NOT CITE OR DISTRIBUTE WITHOUT PERMISSION OF AUTHORS}

A final part of the regulatory design puzzle that we address in this Essay is the importance of salience. In a world of limited resources, it is important to ask the "relative priority" question in designing the regulatory process to improve compliance: how important is it for policy makers to improve the design of a particular part of the regulatory process? Rationalizing integration of private enforcers into the public compliance promotion effort clearly holds promise for improving regulatory compliance, in the environmental context and elsewhere. It is clear, however, that very promising opportunities for transforming regulatory design to improve compliance lie in a broader consideration of the roles that all stakeholders can play during the multiple phases of the regulatory process, including some that precede litigation and related ex post processes. In some circumstances, focusing on agency gatekeeping strategies to influence NGOs' capacity to litigate during the ex post stage of formal enforcement could preclude or undermine pursuit of other opportunities to improve regulatory design to enhance compliance that have more potential to produce desired results. ${ }^{21}$ In setting priorities for regulatory re-design this full gamut of possibilities deserves careful attention.

In short, we endorse Professor Engstrom's call to reorient the literature from focusing on a choice between public and private enforcement to assessing how best to integrate these two forms of enforcement. ${ }^{22}$ But we believe this reorientation's chances for success will be greatly enhanced by greater awareness of the broader contextual framework described here. Part I's taxonomy of the regulatory process highlights the first two elements of our framework - the need for "integration on steroids" to understand the interconnectedness of different phases of the regulatory process and the promise of engaging a wide array of key actors throughout that process, not simply rationalization of the roles of the public and private enforcers engaged in $e x$ post litigation. Part II focuses on the third and fourth elements - the importance in regulatory design of understanding an agency's track record and how the regulatory landscape may change in the future. Finally, in an effort to crystallize the importance of salience, Part III provides a brief overview of an EPA initiative to re-invent its promotion of compliance with the Clean Water Act (CWA)'s regulatory requirements. The CWA allows for citizen suits, an enforcement mechanism that has been widely used by NGOs and that has generated considerable judicial scrutiny and academic commentary. Yet, the role of private enforcement is not even on EPA's radar screen as a focus of enhancing compliance with CWA obligations, at least based on the guidance documents and other materials EPA has issued to date. Instead, EPA is clearly giving priority attention to a wide range of other design and implementation challenges. EPA thus appears to believe that the most promising efforts to improve the aspects of regulatory design that bear on compliance lie in initiatives other than rationalizing public and private enforcement, creating an interesting contrast between Professor Engstrom's characterization of agency gatekeeping of private enforcement as a central challenge in the modern regulatory state and the

\footnotetext{
${ }^{21}$ While we focus here on the importance of using a wider lens to revisit regulatory design, we do not deny that efforts to assess public and private enforcement are valuable as well. There is a rich literature on such efforts. See, e.g., Burbank, Farhang \& Kritzer, supra note _, at 661, 671 (noting that the "range of possible combinations of public and private enforcement ... is substantial and complex," and discussing whether to create private actions, the economic incentives for them, and access rules as among the issues to be addressed); Matthew C. Stephenson, Public Regulation of Private Enforcement: The Case for Expanding the Role of Administrative Agencies, 91 VA. L. REV. 93 (2005); Barton H. Thompson, Jr., The Continuing Innovation of Citizen Enforcement, 2000 U. ILL. L. REV. 185 (2000); Barry Boyer \& Errol Meidinger, Privatizing Regulatory Enforcement: A Preliminary Assessment of Citizen Suits Under Federal Environmental Laws, 34 BUFF. L. REV. 833 (1985).

${ }^{22}$ Engstrom, supra note 1, at __ [ms at 5].
} 


\section{DRAFT - PLEASE DO NOT CITE OR DISTRIBUTE WITHOUT PERMISSION OF AUTHORS}

apparent perspective of one prominent agency and its key stakeholders of the central challenges the agency faces.

\section{I. $\quad$ A Proposed Taxonomy of Effective Regulation: A Brief Overview}

Numerous models of regulation, and hence effective regulation, exist. For example, in the environmental field, many commentators characterize traditional regulation as "commandand-control." According to Professors Cole and Grossman, "' [c]ommand-and-control' is in essence a regulatory approach whereby the government 'commands' pollution reductions (e.g., by setting emissions standards) and 'controls' how these reductions are achieved (e.g., through the installation of specific pollution-control technologies)." ${ }^{23}$ Other variations include marketbased approaches to regulation, ${ }^{24}$ ambient-based approaches, ${ }^{25}$ "new governance" approaches, ${ }^{26}$ and adaptive regulation. ${ }^{27}$ Each type of regulation has different features, and requires different things to work well for it to be effective. ${ }^{28}$

Regardless of the type of regulation used, for our purposes in this Essay the salient point is that enforcement, including optimized government gatekeeping of private enforcement, is at most only one feature of an effective regulatory scheme. ${ }^{29}$ While enforcement is often

\footnotetext{
${ }^{23}$ Daniel H. Cole \& Peter Z. Grossman, When Is Command-and-Control Efficient? Institutions, Technology, and the Comparative Efficiency of Alternative Regulatory Regimes for Environmental Protection, 1999 WIS. L. REV. 887, $887 \mathrm{n} .1$ (1999). As others have pointed out, the term command-and-control is a pejorative term whose use arose out an effort by regulated businesses to depict environmental regulation as the product of "overregulation, big government, and bureaucratic zealotry." Richard N.L. Andrews, The EPA at 40: An Historical Perspective, 21 Duke EnVTl. L. \& Pol'y F. 223, 234-35 (2011). See also David M. Driesen \& Amy Sinden, The Missing Instrument: Dirty Input Limits, 33 HARV. ENVTL. L. REV. 65, 76 (2009) (substituting the term "traditional regulation" for "command-and-control regulation" "[t]o avoid confusion and misleading pejorative terminology"). As Cole and Grossman point out, critics of traditional regulation have even equated command-and-control regulation "with 'Soviet-style' regulation and 'socialist central planning,' implying that it is both endemically inefficient and democratically illegitimate." Cole \& Grossman, supra, at 887.

${ }^{24}$ E.g., 42 U.S.C. $\$ \S 7651$ to $7651 o$ (emissions trading program to reduce acid rain).

${ }^{25}$ E.g., 33 U.S.C. $\$ 1313$ (water quality standards); 42 U.S.C. $\$ 7409$ (b) (national ambient air quality standards).

${ }^{26}$ E.g., Karen Bradshaw Schulz, New Governance and Industry Culture, 88 NOTRE DAME L. REV. 2515 (2013); Jason M. Solomon, New Governance, Preemptive Self-Regulation, and the Blurring of Boundaries in Regulatory Law and Practice, 2010 WIS. L. REV. 227; Douglas Nejaime, When New Governance Fails, 70 OHIO ST. L.J. 323 (2009); Orly Lobel, Setting the Agenda for New Governance Research, 89 MINN. L. REV. 498 (2004).

${ }^{27}$ E.g., Robin Kundis Craig \& J.B. Ruhl, Designing Administrative Law for Adaptive Management, __ VAND. L. REV. _ (forthcoming 2014) (discussing three models of regulation, traditional regulation, market-based approaches to regulation, and adaptive regulation), available at $\mathrm{http}$ ://papers.ssrn.com/sol3/papers.cfm?abstract $\mathrm{id}=2222009$. The list in the text is intended to be illustrative, not exhaustive. For a succinct review of several types of regulation, see OfFICE OF TECHNOLOGY ASSESSMENT, ENVIRONMENTAL POLICY TOOLS: A USER'S GUIDE (1995).

${ }^{28}$ Simpson et al., supra note _, at 237-38 (describing different features of command-and-control and selfregulation); Craig \& Ruhl., supra note _ (suggesting that the type of regulation used may affect the salience or importance of attributes or features). Definitions of "effectiveness" vary based not only on the tools or strategies that are supposed to be used in a particular regulatory scheme, but also on regulatory goals.

${ }^{29}$ Some "regulatory" design approaches may not include an enforcement component at all or it may be quite remote or understated, such as EPA's 33/50 strategy. For descriptions of that program, see U.S. Environmental Protection Agency, Office of Pollution Prevention and Toxics, 33/50 Program: The Final Record, EPA-745-R-99-004 (March 1999), available at http://www.epa.gov/opptintr/3350/3350-fnl.pdf; Madhu Khanna \& Lisa A. Damon, EPA's Voluntary 33/50 Program: Impact on Toxic Release and Economic Performance of Firms, 37 J. ENVTL. ECON. \& MGMT. 1 (1999).
} 


\section{DRAFT - PLEASE DO NOT CITE OR DISTRIBUTE WITHOUT PERMISSION OF AUTHORS}

characterized as essential to effective regulation, ${ }^{30}$ it is not enough to achieve desired environmental protection policy objectives. The head of EPA's enforcement office recently acknowledged this reality, noting that " $[\mathrm{w}]$ hile enforcement is an essential part of EPA's compliance program, it is not realistic to think that enforcement alone will get us to the levels of compliance envisioned by our rules." 31

Although it is possible to describe the components of effective regulation in many ways, ${ }^{32}$ we think it has at least five key characteristics: clear norms, achievability, verifiability, an optimal mix of sanctions and rewards, and indicia of legitimacy. ${ }^{33}$ Among other things, adherence to these characteristics should facilitate regulatory compliance, including achieving a "rationalized" or optimal mix of public and private enforcement. Indeed, understanding these characteristics and the inter-relationships among them in the context of a particular regulatory system is, in our view, critical to designing a rationalized mix of such enforcement.

First, regulators should strive for clarity and certainty; the goal should be to create clear expectations for acceptable (and unacceptable) conduct. It is difficult to achieve objectives, for example, without understanding what they are. Participants across the spectrum of interested stakeholders recognize the value of establishing clear standards for regulated parties to meet.

${ }^{30}$ See Markell, Deterrence-Based Enforcement, supra note _. See also Thomas O. McGarity, When Strong Enforcement Works Better than Weak Regulation: The EPA/DOJ New Source Review Enforcement Initiative, 72 MD. L. REV. 1204, 1206 (2013) (describing "what can be accomplished when a regulatory agency and [the Department of Justice] are willing to devote substantial resources to a coordinated deterrence-based enforcement initiative").

${ }^{31}$ Cynthia Giles, Next Generation Compliance, 30 ENVTL. F. 22, 23 (2013).

${ }^{32}$ Efforts to define effective regulation have appeared in assessments of environmental and other forms of regulation. See, e.g., Douglas M. Costle, Environmental Regulation and Regulatory Reform, 57 WASH. L. REV. 409, 423 (1982) (former EPA Administrator listing as characteristics of effective regulation clarity and certainty, reasonableness and fairness, and efficiency and cost-effectiveness); Meredith James, Results-Based Environmental Regulation in Canada: Creative Solution or Re-Branding Regulation?, 19 J. ENV. L. \& PRAC. 139, 143 (2009) ("Effectiveness and efficiency are usually the primary focus of the debate regarding regulatory tool selection. Characteristics of effective regulation include clear, measurable, enforceable standards and mandatory language. Implementation plans work to ensure efficacy by providing clear jurisdiction and/or cooperation between different levels of government, effective compliance and enforcement mechanisms (including incentives and penalties), and adequate resources for both implementation and enforcement."). $C f$. Dr. Paul Harpur, New Governance and the Role of Public and Private Monitoring of Labor Conditions: Sweatshops and China Social Compliance for Textile and Apparel Industry, 38 RUTGERS L. REC. 1, 1 (2010-2011) ("Effective regulation has three essential components. First, the law must develop standards; second, there must be sufficient monitoring of compliance to detect noncompliance; and third, there must be some form of motivation to avoid non-compliance.") (citing STEPHEN BREYER, REGULATION AND ITS REFORM 5 (1982)); Report of the Committee on Ethics, 15 ENERGY L.J. 193, 195 (1994) (listing as components of effective ethics regulation moral resonance, clarity of purposes, non-triviality, practicality, equity, and proportionality). There also is an obvious tension between different regulatory features or objectives. For example, there may be tension between the goal of clarity and simplicity and the capacity to tailor regulation to individual circumstances through the use of differentiated procedural or substantive requirements.

${ }^{33}$ One could easily compartmentalize the features of the regulatory process differently, even if one were to agree with the thrust of our effort. For example, our first two categories overlap to some degree, though we think they are sufficiently distinct to deserve separate treatment. Similarly, one could separate the carrot-oriented approach to promoting compliance and the stick-oriented set of options, which we have combined. Additionally, we have not created a separate element to acknowledge the options for self-regulation that play an increasingly important role in regulation today. Further, achieving desired results is obviously one of the indicia of effectiveness. Our typology is simply intended to provide a big picture sense of different key elements of the regulatory process as conventionally understood. 


\section{DRAFT - PLEASE DO NOT CITE OR DISTRIBUTE WITHOUT PERMISSION OF AUTHORS}

Complaints about indeterminacy are heard from regulated parties as well as members of the public. ${ }^{34}$ The government has internalized this message as well, with the head of EPA's enforcement office recently acknowledging that "we should focus on greater simplicity and clarity [in our regulations]. One of the principles we have learned over years of hard experience is that compliance is better when the rules are simple and clear." ${ }^{35}$ This message is most obviously salient for the development of regulations, ${ }^{36}$ but it is also important in the development of guidance and the exercise of enforcement discretion. ${ }^{37}$

This feature of effective regulation has the potential to influence the agency gatekeeper design dimensions that Engstrom identifies. ${ }^{38}$ We offer two examples to illustrate the connection. First, the clearer the substantive rules that govern the conduct of regulated entities, the lower the risk that courts, responding to suits by NGOs, will accept novel applications of legal mandates that amount to legislative drift. ${ }^{39}$ Under these circumstances, all other things being equal, the need for agencies to exercise veto authority over private enforcement efforts at the retail level should decline. ${ }^{40}$ Second, clear requirements may dramatically reduce the need

\footnotetext{
${ }^{34}$ At the far end of the continuum are cases such as General Elec. Co. v. EPA, 53 F.3d 1324, 1333-34 (D.C. Cir. 1995), in which the D.C. Circuit rejected an EPA enforcement action against GE because EPA's rules did not provide sufficiently clear norms. Probably more typically, lack of clarity leads to delays and increases in transaction costs, and may discourage socially worthwhile activity. See Angela Morrison Uhland, Improving Regulations for Biomass-Based Electrical Generating Facilities, 23 NAT. RESOURCES \& ENV'T 15 (2008). The more likely and more significant the possible enforcement, the more likely indeterminacy will have these effects.

${ }^{35}$ Giles, supra note _, at 24. See also Water Quality Standards Regulatory Clarifications, 78 Fed. Reg. 54,517, 54,521 (proposed Sept. 4, 2013) (to be codified at 40 C.F.R. pt. 131) (highlighting the value of "clear regulatory requirements" and transparency in promoting water protection). Certainty can also help the government perform its responsibilities more efficiently and effectively. See, e.g., EPA OFFICE OF ENFORCEMENT AND COMPLIANCE ASSurance, CleAn WATER ACT ACTION PlAn at 4 (2009) [hereinafter, EPA, CWAP] (noting that EPA's "challenges in protecting the nation's waters have been increased by recent" Supreme Court decisions concerning the scope of the Clean Water Act's coverage because the "substantial confusion and uncertainty arising from those decisions" "have negatively impacted EPA's ability to enforce by significantly increasing the amount of time and resources it takes to bring enforcement actions necessary to protect our waters").

${ }^{36}$ See, e.g., Vincent Di Lorenzo, Principles-Based Regulation and Legislative Congruence, 15 N.Y.U. J. LEGIS. \& PUB. POL'Y 45, 89 (2012) (citing research that “demonstrates that certainty in statutory or regulatory mandates increases the likelihood of compliance").

${ }^{37}$ For an interesting case study, see Melissa K. Scanlan \& Stephanie Tai, Marginalized Monitoring: Adaptively Managing Urban Stormwater, 31 UCLA J. ENVTL. L. \& POL'Y 1 (2013). See also Elizabeth Glass Geltman \& Andrew E. Skroback, Reinventing the EPA to Conform with the New American Environmentality, 23 COLUM. J. ENVTL. L. 1, 53 (1998) (urging creation of a "no action" process in which EPA would provide facility-specific guidance "so that it gives industry a higher degree of certainty than the EPA's existing guidance documents and policy letters"). Cf. Joan H. Krause, Fraud in Universal Coverage: The Usual Suspects (and Then Some), 55 U. KAN. L. REV. 1151, 1156 (2007) (arguing that "the way to achieve a long-term reduction of undesirable activities in such gray areas [of health care insurance regulation] is not higher penalties but regulatory clarity - the practice of revising incomplete, conflicting, and confusing regulatory guidance to make clear exactly what is expected of the provider in the first place"); Amy L. Stein, Reconsidering Regulatory Uncertainty: Making a Case for Energy Storage, 41 F.S.U. L. REV. _ (forthcoming 2014) (arguing that "not all uncertainty is created equal"), available at http://papers.ssrn.com/sol3/papers.cfm?abstract_id=2294056.

${ }^{38}$ See Engstrom, supra note 1, at _ _ [ms at 20] (Table 1) (listing five gatekeeper design dimensions).

${ }^{39}$ See id. at _ _ [ms at 14-15] (discussing the legislative fidelity critique of private enforcement, which includes the risk that private enforcement will yield legislative drift "as private enforcers drive law enforcement efforts in new and democratically unaccountable directions").

${ }^{40}$ There may be other issues that influence design of gatekeeping structures, such as the desired degree of flexibility concerning remedies.
} 


\section{DRAFT - PLEASE DO NOT CITE OR DISTRIBUTE WITHOUT PERMISSION OF AUTHORS}

for private enforcement. A recent Colorado compliance initiative involving hazardous waste rules found that an innovative state initiative to increase understanding of regulatory requirements led to significant improvements in compliance, thereby dramatically reducing the need for enforcement by anyone. ${ }^{41}$ These are simply two examples of the many ways in which the clarity of regulatory requirements influences the need for enforcement generally, and the need for government restraints on private enforcement actions in particular.

Second, regulatory designers should consider the implementability of requirements - the extent to which strategies "will work in the real world - rules with compliance built in," as EPA's head of enforcement put it recently. ${ }^{42}$ For example, in proposing emission control regulations for oil and gas producers under the Clean Air Act (CAA), EPA adopted the strategy of allowing producers simply to inform EPA that they are using air pollution control equipment that EPA has certified rather than testing the equipment itself. EPA's purpose in using this approach is to "make compliance easier and less costly, while improving results . ..."43 As students of regulation are well aware, ease of implementation should not always predominate in regulatory design, because concerns that norms are inadequate may be a principal impetus for the development of more stringent environmental standards and, further, more aggressive approaches such as technology-forcing regulation have been used successfully in some contexts. ${ }^{44}$ Nevertheless, in developing regulatory approaches policy makers need to be mindful of the challenge they are seeking to address and the workability of the strategies they are considering. ${ }^{45}$

\footnotetext{
${ }^{41}$ Joe Schieffelin, et al., Colorado's Hazardous Waste Small Quantity Generator (SQG) Self-Certification Program (April 2013) (on file with the authors).

${ }^{42}$ Giles, supra note _, at 23. For arguments in favor of pragmatic regulatory approaches, see SIDNEY A. SHAPIRO \& Robert L. GLICKSMAN, Risk REGULATION AT RISK: RESTORING A PRAGMATIC APPROACH (Stanford University Press 2003). There is obviously an overlap between this second attribute and certainty, summarized above.

${ }^{43}$ Giles, supra note _, at 23. We do not mean to suggest that self-reporting without any agency oversight would necessarily be an optimal strategy. See, e.g., Schieffelin et al., supra note _ (noting that self-reporting in tandem with agency oversight helped to improve compliance).

44 Technology-forcing regulation has long been an accepted and important tool for achieving environmental protection goals. There have been some notable success stories with what some believed to be aspirational regulations leading to technological developments that facilitated improved performance, in some cases in the face of claims of infeasibility. See Thomas O. McGarity, Radical Technology-Forcing in Environmental Regulation, 27 LOY. L.A. L. REV. 943 (1994); Robert L. Glicksman, Anatomy of Industry Resistance to Climate Change: A Familiar Litany, in Economic Thought AND U.S. Climate Change Policy (David M. Driesen ed., The MIT Press) (2010); Daniel P. Selmi, Impacts of Air Quality Regulation on Economic Development, 13-Fall NAT. RESOURCES \& ENV'T 382, 386 (1998) ("In the past, claims that the pollution control technology is impossible to achieve have collapsed when one manufacturer announced that it was able to comply. "); $c f$. John P. Dwyer, Practice of Federalism under the Clean Air Act, 54 MD. L. REV. 1183 (1995).

${ }^{45}$ The balance described in the text is relevant to both desired normative outcomes and strategies adopted to achieve those outcomes. Beyond the types of questions referenced in the text, there are entire literatures devoted to the appropriate content of regulations. For a review of economists' perspectives on regulatory design, see, e.g., Thomas P. Lyon, Environmental Governance: An Economic Perspective, in GOVERNANCE FOR THE ENVIRONMENT, supra note _, at 43; Giles, supra note _, at 24 (noting that market strategies "can be simple and effective in the right circumstances, reducing costs and providing flexibility for industry while achieving better results"). For a procedural justice perspective, see David Markell, Tom Tyler \& Sarah F. Brosnan, What's Love Got to Do with It?: Sentimental Attachments and Legal Decision-making, 57 VILL. L. REV. 209 (2012). For a political science perspective, see Maria Carmen Lemos \& Arun Agrawal, Environmental Governance and Political Science, in GOVERNANCE FOR THE ENVIRONMENT, supra note __, at 69; and for a management scholar perspective, see Andrew
} 


\section{DRAFT - PLEASE DO NOT CITE OR DISTRIBUTE WITHOUT PERMISSION OF AUTHORS}

This feature of regulatory effectiveness is also relevant to the dynamics of agency gatekeeping as a mechanism for rationalizing public and private enforcement. For example, unanticipated regulatory implementation problems may make compliance very costly or not possible at all by applicable regulatory deadlines. Public enforcers might choose to exercise prosecutorial discretion and defer prosecution of known violations, perhaps in return for commitments by regulated entities to sink resources into developing a fix for the implementation problem. Private enforcement may disrupt such negotiations, interfering with commitments that regulated entities might otherwise make to public enforcers. In such circumstances, the arguments in favor of a strong public gatekeeping role for private enforcement actions may be relatively appealing.

A third key feature of effective regulation and of strategies to induce compliance involves what we term "verifiability." This includes the capacity to monitor compliance with regulatory requirements to promote accountability. Monitoring schemes come in various shapes and sizes. The type of monitoring required may depend on availability of government resources, the complexity associated with the monitoring required, the reliability of monitoring equipment, the trustworthiness of regulated parties, and the transparency of the information developed and provided, among others factors. ${ }^{46}$ Reflecting the variation in approaches that are possible, one of us was involved many years ago in establishing a statewide strategy that sought to enhance "verifiability" by requiring facilities with especially significant compliance concerns to hire independent third-party monitors whose role was to complement both government inspection efforts and the facility's own compliance efforts. ${ }^{47}$

The verifiability of regulatory compliance may affect the optimal design of agency gatekeeping functions. For example, the easier and cheaper it is for private enforcers to acquire information revealing compliance status, the greater the likelihood that the kind of

\footnotetext{
King \& Michael W. Toffel, Self-Regulatory Institutions for Solving Environmental Problems: Perspectives and Contributions from the Management Literature, in id. at 98.

${ }^{46}$ Monitoring can take several forms, such as the requirement that regulated entities file periodic discharge monitoring reports (DMRs), as under the Clean Water Act, see 40 C.F.R. §§ 122.2 (defining DMRs), 122.41(l)(4)(i) (requiring filing of such reports), or the obligation for industrial facilities to report annual releases of specified chemicals under the Emergency Planning and Community Right-to-Know Act. See U.S. EPA, Toxic Release Inventory Program, http://www2.epa.gov/toxics-release-inventory-tri-program. DMRs are compliance-based, while chemical release forms are not strictly so but can indirectly provide clues about environmental performance generally and compliance in particular. Verifiability tools vary in their degree of transparency. Some commentators have highlighted the importance of broader transparency to the public as a part of verifiability. See Markell, Slack, supra note _, at 8-10 (discussing increases in transparency and public involvement in the environmental regulatory process). EPA's view at least is that "[p]ublic disclosure is [an] underutilized tool: there is powerful evidence that publishing information about company performance drives better behavior, as pressure is applied by customers, neighbors, investors, and insurers." Giles, supra note _, at 24. A 2008 study in Massachusetts found that "drinking water systems required to mail the reports to customers reduced their total violations by 30-44 percent as a result of this new reporting, and reduced the more severe health violations by 40-57 percent. . . EPA's efforts to make our data more available are only starting to scratch the surface of the ways transparency can improve results." Id. at 25 . Further, Giles indicates that transparency may serve a "reminder function": "publishing data on facility performance draws attention to problems and brings senior-level focus to bear on fixing them." Id. In addition, it may bring community pressure to bear on lower performing parties and may alert investors and insurers in ways that provide financial motivation to improve performance. Id. at 25-26.

${ }^{47}$ See David L. Markell, States and Innovators: It's Time for a New Look to Our "Laboratories of Democracy" in the Effort to Improve Our Approach to Environmental Regulation, 58 ALB. L. REV. 347, 408 (1994).
} 


\section{DRAFT - PLEASE DO NOT CITE OR DISTRIBUTE WITHOUT PERMISSION OF AUTHORS}

overdeterrence that Engstrom describes in discussing another critique of private enforcement, the "zealousness critique," will occur because the expected return will exceed the low cost of private enforcement. ${ }^{48}$ In such circumstances, the result may be a deviation between the private and social value of enforcement.

A fourth attribute of an effective regulatory scheme is its capacity to incentivize regulated parties to achieve optimal levels of compliance. The mix of compliance-inducing tools includes strategies intended to deter undesirable behavior as well as approaches that encourage desired performance. $^{49}$ The literature often refers to enforcement schemes that provide general as well as specific deterrence in order to encourage optimal levels of compliance with the law. ${ }^{50}$ In addition, the evolving literature in the management area, among others, suggests that various types of "carrots" also have potential to promote compliant behavior. ${ }^{51}$

Rationalizing private and public enforcement litigation in order to improve the capacity of enforcement actions to deter noncompliance is one of many strategies that falls within this fourth attribute or feature of effective regulatory design. ${ }^{52}$ Our expanded focus suggests the importance of considering private and public enforcement in the context of other available approaches in order to rationalize use of such enforcement. EPA, for example, may want to encourage private enforcement litigation in circumstances in which other forms of inducing compliance, such as reliance on positive incentives, do not yield desired levels of compliance and in which obstacles (such as resource limits) exist to traditional government deterrence-based enforcement. Similarly, EPA may want to be a strict "gatekeeper" if it is concerned that use of private enforcement will undermine national consistency in approaching compliance challenges. For example, private party enforcement efforts that focus on securing particular types of relief with which EPA has concerns in lieu of the types of relief EPA favors may influence the choice

\footnotetext{
${ }^{48}$ See Engstrom, supra note 1, at _ [ms at 10-12]. This critique entails systematic over-expenditure of social resources and costly over-deterrence when private enforcers pursue actions that public enforcers choose not to pursue because the expected cost exceeds the expected social gain. The problems associated with the zealousness critique arise from deviations in assessments by public and private enforcers of the relative costs and value of enforcement. Id.

${ }^{49}$ See Lyon, supra note _ , at 49-52 (discussing the impacts of various alternative policy instrument choices, such as subsidies and effluent fees). Cf. McGarity, supra note_, at 1207 (arguing that "a carefully selected enforcement initiative may accomplish more than a major assistance-based rulemaking initiative").

${ }^{50}$ See generally Markell, Deterrence-Based Enforcement, supra note _; Rechtschaffen \& Markell, supra note __. See also Robert L. Glicksman \& Dietrich H. Earnhart, The Comparative Effectiveness of Government Interventions on Environmental Performance in the Chemical Industry, 26 STAN. ENVTL. L.J. 317, 331-36 (2007).

${ }^{51}$ Lyon, supra note __, at 49-52. See Markell, Deterrence-Based Enforcement, supra note _, at 14-29 (discussing the potential for positive impacts on compliance from incentive policies); Robert F. Blomquist, Models and Metaphors for Encouraging Responsible Private Management of Transboundary Toxic Substances Risk: Toward a Theory of International Incentive-Based Environmental Experimentation, 18 U. PA. J. INT'L ECON. L. 507,556 (1997) (discussing "challenge regulations" which "have the potential to entice and stimulate creative, innovative, and cost-effective experimentation by private industrial firms"). A lot remains to be learned about the effectiveness of different strategies. See, e.g., Simpson et al., supra note _, at. 233 (noting that "scholars and policymakers know very little about 'what works, what doesn't, and what's promising' regarding corporate crime-control strategies"). For a recent example of an initiative that dramatically improved compliance rates without any enforcement, see Schieffelin, supra note _, at _.

${ }^{52}$ See, e.g., Engstrom, supra note 1, at _ [ms at 30] (arguing that "an ideal gatekeeper agency focused on optimal deterrence will join and leverage the enforcement efforts of overmatched private enforcers who will not otherwise fully vindicate the public interest").
} 


\section{DRAFT - PLEASE DO NOT CITE OR DISTRIBUTE WITHOUT PERMISSION OF AUTHORS}

of gatekeeping approaches because of not only legislative fidelity, but also coordination issues, ${ }^{53}$ to use Engstrom's terms. ${ }^{54}$

Finally, we suggest that an important aspect of effective regulation is its capacity to promote legitimacy, which we define to include enhancing confidence by the public and others. ${ }^{55}$ We believe that, in pursuing optimal regulatory design in the compliance arena, it is appropriate to ask questions about the effects of different design options on public perceptions. Will a particular regulatory design enhance or diminish public confidence in a regulatory program and the government's ability and willingness to ensure compliance with it? A regulatory scheme that leads to a public perception that government is corrupt, overbearing, or selective may lead to a loss of confidence and trust that undermines effective regulation in many ways, including by exacerbating budget pressures if public support for necessary funding diminishes. ${ }^{56}$ Similarly, an enforcement strategy that relies entirely on regulated entities' oversight of their own performance, without verification or transparency of documentation of regulatory compliance, is likely to engender distrust and raise the specter of capture by regulated entities. ${ }^{57}$ Given the

\footnotetext{
${ }^{53}$ The third critique of private enforcement that Engstrom identifies (in addition to the zealousness and legislative fidelity critiques) is what he calls the "coordination critique." The problems include wasteful duplication of effort and a lack of coherence that disrupts cooperative relationships between regulators and regulatory targets. Id. _ [ms at 12-14].

${ }^{54}$ This issue has arisen in the context of supplemental environmental projects (SEPs), among others. See David L. Markell, Is There a Possible Role for Regulatory Enforcement in the Effort to Value, Protect, and Restore

Ecosystem Services?, 22 J. OF ENVTL.\& LAND USE L. 549 (2007).

${ }^{55}$ For one effort to raise this fifth feature of regulation in a different context, see John H. Knox \& David L. Markell, Evaluating Citizen Petition Procedures: Lessons from an Analysis of the NAFTA Environmental Commission, 47 TEX. INT'L L.J. 505 (2012). For discussions of the difficult-to-define concept of legitimacy, see, e.g., Sidney A. Shapiro, et al., The Enlightenment of Administrative Law: Looking Inside the Agency for Legitimacy, 47 WAKE FOREST L. REV. 463, 466 (2012) (noting that "Legitimacy is a notoriously treacherous concept."). One way to define the term is to focus on "the acceptability of [a] regulation to those involved in its development." Jody Freeman \& Laura I. Langbein, Regulatory Negotiation and the Legitimacy Benefit, 9 N.Y.U. ENVTL. L.J. 60, 63 (2000). Such acceptability may hinge on the availability of opportunities for public participation and the degree of transparency provided by a regulatory scheme. The legitimacy of a regulatory system also may turn on the degree to which it protects against deviation from legislative goals due to capture of regulators by special interests, and on whether decision makers are perceived of as honest, unbiased, or competent. See Camacho \& Glicksman, supra note __, at ___ (Part I.D).

56 The controversy concerning the IRS's purported selection bias in targeting "tea party" groups is a recent example. See Sheila Krumholz \& Robert Weinberger, The Real I.R.S. Scandal, N.Y. TIMES, May 15, 2013 , at A27 (“[E]ven more regrettable is the long-term damage to the credibility of the I.R.S. as an impartial arbiter of whether organizations merit tax-exempt status. This will be difficult to undo. . ..”); Rachel E. Barkow, Prosecutorial Discretion: Prosecutor Bias and the Department of Justice, 99 VA. L. REV. 271 (2013) (raising concerns about unfettered prosecutorial discretion).

${ }^{57}$ See William L. Andreen, Motivating Enforcement: Institutional Culture and the Clean Water Act, 24 PACE ENVTL. L. REV. 67, 71 (2007) ("EPA enforcement, unfortunately, is quite vulnerable to administrative or political manipulation because the level and quality of EPA enforcement activity is not particularly transparent."). Colorado's recent case study of an initiative that relies on both self-certification and random agency follow-up inspections reflects that carefully designed self-certification efforts can dramatically improve compliance. See Schieffelin, supra note _ at, 10, 11, 18 (noting that a self-certification program involving small quantity generators under the Resource Conservation and Recovery Act "has attained very impressive compliance rate improvements in the SQG universe in Colorado over the last four years," and reporting that the percent of such facilities in $100 \%$ compliance with all regulatory requirements increased from $31 \%$ in 2008 to $84 \%$ in 2011).
} 


\section{DRAFT - PLEASE DO NOT CITE OR DISTRIBUTE WITHOUT PERMISSION OF AUTHORS}

polling results showing the American public's loss of confidence in the federal government, ${ }^{58}$ we believe that it is appropriate for those interested in regulatory design to consider this feature of effective regulation in considering design options. ${ }^{59}$

The legitimacy of a regulatory program and the manner in which an agency implements it may bear on gatekeeping design choices as well. Engstrom discusses "bubble periods," during which regulatory mandates remain unsettled, in part because of the costs of complying with procedures for adoption of regulatory mandates. ${ }^{60}$ He posits that vigorous private enforcement may be troublesome during these transitional periods because judicial responses to private enforcement actions may be difficult to override legislatively and enforcement targets may suffer costly adverse judgments notwithstanding subsequent overrides. In such cases, allowing private enforcement might undermine legitimacy in the eyes of the regulated community at a minimum. This effect would support a strong gatekeeping regime. But if agency delay in filling statutory gaps is due not to the costs of regulation but instead to agency disaffection with the statutory regime, private enforcement may help to maintain public confidence in the rule of law. This scenario would seem to favor a weak gatekeeping regime.

We conclude this brief introduction to key features of the regulatory process with three observations. First, a key purpose of this Part is to demonstrate that the features or attributes of regulatory design are interrelated rather than distinct. ${ }^{61}$ The need for and viability of ex post enforcement, and the design of public gatekeeping options (Professor Engstrom's focus and a part of the fourth attribute of effective regulatory compliance structures enumerated above), for example, is likely to depend on the clarity of the norms (the first attribute), their implementability (the second attribute), the quality of monitoring and dissemination of compliance information (the third attribute), and the use of other compliance-promotion tools (i.e., other strategies that could be included as part of the $4^{\text {th }}$ attribute). Thus, it is critical to understand the entire regulatory process not only in designing an overall regulatory program capable of meeting statutory goals, but also in making informed judgments about narrower

\footnotetext{
${ }^{58}$ See e.g., Joy Wilke \& Frank Newport, Fewer Americans than Ever Trust Government to Handle Problems, GALLUP POLITICS, Sept. 13, 2013, http://www.gallup.com/poll/164393/fewer-americans-ever-trust-gov-handleproblems.aspx . Some individual agencies, including EPA, tend to poll much higher, however. At the same time that only $19 \%$ of respondents in one poll answered that they trust the government to do what is right almost always or most of the time, and only $23 \%$ viewed Congress favorably, $62 \%$ of respondents viewed EPA favorably. Pew Research Center, Trust in Government Nears Record Low, but Most Federal Agencies Are Viewed Favorably (Oct. 18, 2013), available at http://www.people-press.org/files/legacy-pdf/10-18$13 \% 20$ Trust $\% 20 \mathrm{in} \% 20 \mathrm{Govt} \% 20 \mathrm{Update} . \mathrm{pdf}$

${ }^{59}$ As indicated above, this set of five attributes of effective governance is not intended to be exhaustive or comprehensive. Instead, our intent is to highlight some of the key features of effective regulation. While we did not highlight the need for adequate funding and other resources, as well as stakeholder support, specifically, these also are important to governance's capacity to be effective in advancing objectives. See, e.g., Craig \& Ruhl, supra note $\ldots$, at 26 (making this point in the context of adaptive management).

${ }^{60}$ Engstrom, supra note 1, at __ [ms at 16].

${ }^{61}$ The reference to transparency as an attribute that is relevant to legitimacy, for example, reflects the overlap among our categories, as transparency is also often a feature of verifiability.
} 


\section{DRAFT - PLEASE DO NOT CITE OR DISTRIBUTE WITHOUT PERMISSION OF AUTHORS}

aspects of optimal regulatory design, such as compliance promotion generally or even the appropriate regulatory design of government gatekeeping of private enforcement. ${ }^{62}$

Second, hybrid governance, or "pluralistic regulatory governance," to use Professor Engstrom's term, is a critical component of the search for effective regulatory compliance structures. As Professor Engstrom highlights, over time private NGOs have taken on an increasing role in ex post enforcement of the environmental laws, and this expanded role is likely to continue for some time. This form of hybrid governance, however, is only the tip of the iceberg. A wide range of NGOs today plays critical roles that affect each of the five attributes or features of regulatory design we outline above. For example, involvement of key stakeholders in the development of norms can help to produce clarity (characteristic 1 of effective regulation), their engagement is essential in considering feasibility (characteristic 2), and verifiability (characteristic 3) depends on the engagement of regulated parties but also benefits from public involvement. In short, the search for optimal governance benefits from consideration of options for integrating NGOs throughout the regulatory process. ${ }^{63}$ Engstrom implicitly highlights the importance of this issue in the search for regulatory design, but it deserves treatment well beyond public gatekeeping of private enforcement. Instead, it is important to consider the implications of hybrid governance across the entire regulatory landscape. ${ }^{64}$

A final point, which is implicit in our preceding summary of the features of effective regulation and on which we focus in Part III below, is that the possibilities for optimal governance are dynamic, as the capacities of different actors evolve. For example, advances in technology that facilitate better monitoring and data management hold promise for transforming governance in ways that overcome some of the more pressing historic and contemporary challenges. EPA is relying on these new tools heavily as it pursues improved regulatory design to address the compliance challenges it faces. ${ }^{65}$

Our purpose in this Part is to support our claim that the search for optimal regulatory design requires an understanding of the entire regulatory process and of the actors who play critical roles throughout that process, whether the goal is optimal regulatory design for a regulatory scheme writ large, or optimal regulatory design of a particular piece of that scheme. We now turn to a brief review of some of the real-world compliance-related challenges and

\footnotetext{
${ }^{62}$ See Esworthy, How Are They Enforced?, supra note _, at 5 (noting that policy makers continue to wrestle with the challenge of "how to balance punishment and deterrence through litigation with compliance assistance, incentive approaches, self-auditing or correction, and voluntary compliance")

${ }^{63}$ The dynamic nature of "new governance" approaches is important to bear in mind, as the predilections of different actors change over time. See, e.g., Grabosky, supra note _, at ___ (suggesting that the increased role of NGOs in governance stems in part from a retreat by government that has created a regulatory vacuum). Grabosky suggests that "regulatory space is contested, and resulting relational interactions between institutions are often complex." Id. at 116. Some favor some degree of orchestration of different actors (Engstrom falls into this camp, as do we), while others "may see a regulatory system characterized by spontaneity as inevitable." Id. at 115-16.

${ }^{64}$ Others have highlighted this reality as well and agencies have recognized some of the opportunities. EPA, for example, initiated the "National Report a Violation" website in 2006 in an effort to encourage citizens to report potential environmental violations, part of the "verifiability" characteristic we describe above. Esworthy, How Are They Enforced?, supra note __, at 14. See also EPA-OECA, Report on Environmental Violation, http://www.epa.gov/tips.

${ }^{65}$ See infra Part III.
} 


\section{DRAFT - PLEASE DO NOT CITE OR DISTRIBUTE WITHOUT PERMISSION OF AUTHORS}

opportunities EPA faces, before considering in the final Part some regulatory design options that EPA is currently exploring in the context of the strategies that Professor Engstrom discusses.

\section{Contextualizing the Conceptual Framework for Effective Regulatory Compliance Design:} An Overview of EPA's Compliance Track Record and Challenges

Professor Engstrom has helpfully expanded the debate about optimal regulatory design of the enforcement function beyond assessments of the appropriateness of litigation reforms by suggesting the relevance of gatekeeping design options. In Part I, focusing on the operation of EPA, we argued that a broader range of regulatory features is relevant to effective regulation, including effective enforcement, and provided examples of how these features are inter-related; in particular, we explained how different features may affect gatekeeping design. In this Part we provide additional context by reviewing EPA's enforcement track record and capacity and explain how they relate to the optimal design of compliance approaches generally, and of gatekeeping approaches in particular.

Evaluating effectiveness in inducing compliance is an extraordinarily difficult task. ${ }^{66}$ It is worth being mindful of the old adage about optimists seeing the glass half full and pessimists seeing the same glass as half empty in considering EPA's performance and appraisals of its enforcement efforts. Nevertheless, a wide variety of observers, inside and outside government, have identified significant concerns over EPA efforts to promote compliance. EPA faces substantial barriers in overcoming these challenges, including resource constraints (its own and those of the states), and a changing (in some cases expanding) regulated community. There are, however, some promising signs on the regulatory design horizon as well.

\footnotetext{
${ }^{66}$ Esworthy, How Are They Enforced?, supra note _, at 5, 40 (noting that "how best to measure the success and effectiveness of enforcement" is an issue of continuing interest and that "[f]ully evaluating and measuring the overall effectiveness of current (and past) pollution control enforcement and compliance activities can be quite complicated"). EPA acknowledged this reality recently in a draft strategy for improving oversight of state enforcement performance. U.S. Environmental Protection Agency, National Strategy for Improving Oversight of State Enforcement Performance 2-3 (Aug. 27, 2013 draft) [hereinafter EPA, Improving Oversight], available at http://environblog.jenner.com/files/national-strategy-for-improving-oversight-of-state-enforcement-performance.pdf (link provided in Steven M. Siros, EPA Proposes Increased Oversight Of State Enforcement Activities (Oct. 18, 2013), available at http://environblog.jenner.com/corporate environmental_1/2013/10/epa-proposes-increasedoversight-over-state-enforcement-activities.html) (noting that "[m]easuring state [enforcement] performance is a complex undertaking" and further noting that EPA's data alone "cannot tell us what we need to know about performance" for a variety of reasons, including because EPA's current metrics are "based on the activities the states perform and not on the level of compliance within regulated sectors, which is difficult to assess with the information currently available"). There is an extensive measurement literature. The Government Performance and Results Act (GPRA), in its various manifestations, represents an effort to focus on results and their measurement. See, e.g., Office of Management and Budget, Delivering on the Accountable Government Initiative and Implementing the GPRA Modernization Act of 2010 (April 14, 2001), M-11-17, available at http://www.whitehouse.gov/sites/default/files/omb/memoranda/2011/m11-17.pdf; Lori S. Bennear \& Katherine Dickinson, Incorporation Evaluation into the Regulatory Process, Duke Environmental Economics Working Paper Series, Working Paper EE 11-06 (July 2011), available at http://sites.nicholasinstitute.duke.edu/environmentaleconomics/files/2013/01/WP-EE-11-06.pdf; U.S. Government Accountability Office, Managing for Results: GPRA Modernization Act Implementation Provides Important Opportunities to Address Government Challenges (May 10, 2011, GAO-11-617T), available at http://www.gao.gov/products/GAO-11-617T; Shelley H. Metzenbaum, Performance Accountability: The Five Building Blocks and Six Essential Practices, IBM Center for The Business of Government (2006), available at http://www.acquisition.gov/sevensteps/library/PerformanceAccountability.pdf.
} 


\section{DRAFT - PLEASE DO NOT CITE OR DISTRIBUTE WITHOUT PERMISSION OF AUTHORS}

The salient point about the contextual overview we provide in this Part is that extant and upcoming challenges, as well as emerging opportunities, demonstrate that efforts to improve "regulatory design," even of particular aspects of regulatory regimes such as gatekeeping strategies, should be made with an understanding of the nature of the challenges an agency faces and the tools available to meet those challenges. For example, concerns that a regulatory design that enables private enforcement suits will lead to the problems with private enforcement that Engstrom discusses (overzealousness, coordination challenges, or infidelity to legislative objectives) are likely to be fairly minor in a context in which there is rampant non-compliance, violations are causing significant environmental degradation and harm to public health, and responsible agencies have proved incapable of or unwilling to enforce even the most egregious violations. On the other hand, such concerns are likely to be much more relevant when compliance challenges are complex and require sophisticated, integrated strategies, and a responsible agency's efforts to address these challenges efficiently and effectively are likely to be undermined by the presence of a host of other erstwhile enforcers.

\section{A. Agency Enforcement Records}

The Government Accountability Office (GAO), EPA's Inspector General, EPA's Administrator, and EPA's own enforcement office have offered highly critical assessments of EPA's performance in promoting compliance with environmental regulatory requirements. ${ }^{67}$ In a December 2012 report, for example, the GAO noted that "[i]n recent years, EPA has reported that it is not achieving all of the environmental and public health benefits it expected in regulating certain entities because of substantial rates of noncompliance in some programs. ${ }^{68}$ Compounding the challenge in achieving optimal levels of compliance is the reality that, as the GAO also noted, "because of incomplete or unreliable data on compliance in some programs, such as the NPDES [permit program under the CWA], EPA cannot determine the full extent of entities' compliance." 69

Concerns about government enforcement extend beyond EPA's performance. An essential feature of environmental regulation is its reliance on a cooperative federalism structure. Congress has enacted pollution control laws such as the CAA and CWA, charging EPA with ultimate responsibility for implementing these laws and achieving their goals. It has also empowered qualified and interested states, however, to take over primary implementation, notably planning, permitting, and enforcement, under laws states adopt for that purpose. ${ }^{70}$ Over the years, EPA has authorized increasing numbers of states to take primary responsibility for implementation of the major environmental laws, and the states are regarded as the primary

\footnotetext{
${ }^{67}$ For a recent collection of some of the reviews, see Esworthy, How Can They Be Enforced?, supra note _, at 2-4.

${ }^{68}$ U.S. General Accountability Office, EPA Should Develop a Strategic Plan for Its New Compliance Initiative, GAO-13-115, at 1-2 (Dec. 2012), available at http://www.gao.gov/assets/660/650711.pdf [hereinafter GAO, Strategic Plan].

${ }^{69} I d$. at 1-2. NPDES is the acronym for the National Pollutant Discharge Elimination System permitting program. See infra Part III for additional discussion of concerns about EPA's enforcement record.

${ }^{70}$ For a description of cooperative federalism under federal environmental statutes, see generally Robert $\mathrm{L}$. Glicksman, From Cooperative to Inoperative Federalism: The Perverse Mutation of Environmental Law and Policy, 41 WAKE FOREST L. REV. 719 (2006).
} 


\section{DRAFT - PLEASE DO NOT CITE OR DISTRIBUTE WITHOUT PERMISSION OF AUTHORS}

enforcers under the major federal environmental regulatory statutes. ${ }^{71}$ As a result, much of the compliance promotion work is now done by the states with oversight from EPA. According to one account, states conduct about ninety percent of all environmental regulatory inspections and file eighty to ninety percent of environmental enforcement actions. ${ }^{72}$ Thus, assessments of the efficacy of state performance are (or to be plausible must be) at the heart of efforts to evaluate government enforcement performance more generally. ${ }^{73}$

The GAO and EPA's Office of Inspector General (OIG), among others, have documented significant deficiencies in states' performance. ${ }^{74}$ As the GAO noted in 2012, both it and the OIG have reported inconsistencies in state environmental enforcement, and the OIG characterized state enforcement programs as "underperforming," notwithstanding EPA's efforts to improve state performance and oversight consistency. ${ }^{75}$

EPA's enforcement office also has acknowledged serious deficiencies in state performance. In its draft August 2013 National Strategy for Improving Oversight of State Enforcement Performance, EPA noted that its reviews of state performance found that "four significant issues in particular continue to be "unresolved and recurring," and to require a focused national effort to address them:

- Widespread and persistent data inaccuracy and incompleteness in national data systems, which make it hard to identify when serious problems exist or to track state actions;

- Routine failure of states to identify and report significant noncompliance;

- Routine failure of states to take timely or appropriate enforcement actions to return violating facilities to compliance, potentially allowing pollution to continue unabated; and

- Failure of states to take appropriate penalty actions, which results in ineffective deterrence for noncompliance and an unlevel playing field for companies that do comply. ${ }^{76}$

\footnotetext{
${ }^{71}$ See McAllister, supra note __ , at 21 ("In many regulatory programs, states have the primary responsibility for enforcement and are overburdened."); CLIFFORD RECHTSCHAFFEN \& DAVID L. MARKELL, REINVENTING

ENVIRONMENTAL ENFORCEMENT AND THE STATE/FEDERAL RELATIONSHIP 43 (2003) ( "Congress established a 'cooperative federalism' structure that makes EPA ultimately responsible for program delivery while reserving the primary front lines implementation role for willing and capable states.").

${ }_{72}$ McAllister, supra note _, at 21. See also Esworthy, How Are They Enforced?, supra note significant proportion of inspections and enforcement actions are conducted by the states.").

${ }^{73}$ See Esworthy, How Can They Be Enforced?, supra note__, at 3 (noting that in light of the states' substantial role under federal pollution controls statutes, "state autonomy versus the extent of federal oversight is often at the center of debate with regard to environmental enforcement") .

${ }^{74}$ See, e.g., Esworthy, How Can They Be Enforced?, supra note _, at 2 n. 5 (collecting sources); U.S. EPA Office of Inspector General, EPA Must Improve Oversight of State Enforcement, http://www.epa.gov/oig/reports/202/20111209-12-P-0113.pdf (2011) [hereinafter OIG, Improve Oversight]; U.S. Memorandum, Robert Perciasepe and Cynthia Giles to Arthur Elkins, Inspector General (March 12, 2013); CWAP, supra note __, at _..

${ }^{75}$ GAO, Strategic Plan, supra note _ , at 1-2.

${ }^{76}$ EPA's reviews, conducted under the agency's State Review Framework (SRF), are available at http://www.epa.gov/compliance/state/srf/index.html (2004-2012). See also EPA, Improving Oversight, supra note $\ldots$ _. at 11, 15-16 (identifying limited information and inconsistencies in EPA databases concerning state enforcement
} 


\section{DRAFT - PLEASE DO NOT CITE OR DISTRIBUTE WITHOUT PERMISSION OF AUTHORS}

The upshot is that, as EPA's OIG has found, "state enforcement programs frequently do not meet national enforcement goals."77 The Inspector General found that during fiscal years 2003 to 2009, which was before some of the most significant funding declines described below occurred, "performance was low across the board," with some states performing far below average. $^{78}$ For example, EPA established a national goal that states inspect $100 \%$ of major CAA emitters every two years, but the Inspector General found that only eight states met that goal. As of 2009, EPA set a national goal that states inspect $100 \%$ of CWA major permit holders every two years, but in 2010, only two states met that goal, the national average was only $61 \%$, and 13 states inspected fewer than $50 \%$ of major facilities. ${ }^{79}$ Similarly, only two states met EPA's target for inspections of hazardous waste generators under RCRA, and states averaged inspections at only $62 \%$ of the targeted number of facilities. ${ }^{80}$ The Inspector General concluded that EPA had failed to hold its regional offices accountable for ensuring that states adequately enforce environmental laws, and that EPA regions did not consistently intervene to correct state deficiencies. $^{81}$

Given these challenges, as well as growing federal and state budget pressures, EPA observed that it has become increasingly difficult to rely primarily on its traditional approach of inspecting individual entities to increase compliance with the nation's environmental laws and regulations. ${ }^{82}$ EPA recently announced a new initiative-Next Generation Compliance - to improve performance by capitalizing on advances in emissions monitoring and information technology. ${ }^{83}$

\section{B. Declining Resources}

The adequacy of government resources to promote compliance to optimal levels has been a long-standing concern that seems unlikely to be addressed in the near term. Most of EPA's annual funding comes from discretionary appropriations. The agency's funds increased sharply in the late 1970s, as EPA began implementing many of the foundational environmental laws

and noting that EPA has had enormous difficulties in "accurately and consistently tracking the size of the regulated populations").

${ }_{77}^{7}$ OIG, Improve Oversight, supra note __, at 8 (Dec. 9, 2011).

${ }^{78} I d$. at 8 .

${ }^{79} \mathrm{Id}$. at 9.

${ }^{80} \mathrm{Id}$. at 10.

${ }^{81} \mathrm{Id}$. at 11,15 . Statistics such as the number of enforcement actions brought or the amount of penalty dollars recovered in enforcement actions do not necessarily correlate with either levels of environmental protection achieved or levels of compliance. The need for enforcement action may fall, for example, if earlier steps in the regulatory process have succeeded in making compliance easier and motivating regulated entities to comply. Nevertheless, EPA has acknowledged problems in some states' records on enforcement of the federal statutes and in EPA regional offices' oversight of these programs. See EPA, Improving Oversight, supra note _, at 2-3 ("EPA's current metrics [for state enforcement activity] are based on the activities the states perform and not on the level of compliance within regulated sectors, which is difficult to assess with the information currently available.").

${ }^{82}$ GAO, Strategic Plan, supra note __, at 1-2.

${ }^{83}$ See Giles, supra note _. The GAO has reviewed this plan and suggested, among other things, that EPA develop a "strategic plan to integrate Next Generation Compliance into its enforcement and compliance program." GAO, Strategic Plan, supra note _, at 8. EPA is in the process of doing so. Id. at 9. 


\section{DRAFT - PLEASE DO NOT CITE OR DISTRIBUTE WITHOUT PERMISSION OF AUTHORS}

adopted earlier that decade. ${ }^{84}$ Funding dipped in the early 1980s and then leveled off until late in that decade, after which it increased fairly regularly until fiscal year 2005. The enacted budget for the agency fell slightly for fiscal years 2006 through 2009 (returning to levels experienced during the late 1990s), before reaching a peak of $\$ 10.3$ billion in fiscal year 2010 and then declining to about $\$ 8.5$ billion in fiscal years 2011 and 2012, and a little less in fiscal year 2013. ${ }^{85}$ Adjusted for inflation, however, EPA's funding in fiscal year 2009 was slightly lower than it was in fiscal year 1978 , according to the Congressional Research Service. ${ }^{86}$

The impact of a drop in real funding is magnified by the increase in EPA's regulatory responsibilities that occurred between 1978 and 2009 as a result of the enactment of new statutory programs (such as the Comprehensive Environmental Response, Compensation, and Liability Act in $1980^{87}$ and the Emergency Planning and Community Right-to-Know Act in $1986^{88}$ ) and the expansion of regulatory programs - often in ways that drew many new sources within the scope of those programs - through amendments to RCRA in $1984,{ }^{89}$ the CWA in $1987,{ }^{90}$ and the CAA in $1990 .{ }^{91}$ In each successive fiscal year since 2009, EPA's funds have fallen. ${ }^{92}$ Further cuts, perhaps very significant ones, seem almost inevitable, at least in the near term. ${ }^{93}$ Environmental group spokespersons have characterized budget cuts for EPA as an

\footnotetext{
${ }^{84}$ EPA's budget increased from $\$ 770$ million dollars in fiscal year 1976 to $\$ 2.7$ billion in fiscal year 1977 to $\$ 5.4$ billion in both fiscal years 1978 and 1979. U.S. EPA, EPA's Budget and Spending, http://www2.epa.gov/planandbudget/budget.

${ }^{85}$ U.S. EPA, EPA's Budget and Spending, http://www2.epa.gov/planandbudget/budget. EPA received \$14.8 million in appropriated funds in fiscal year 2009, but about half of that amount took the form of emergency supplemental appropriations under the American Recovery and Reinvestment Act of 2009, Pub. L. No. 111-5, 123 Stat. 115. Robert Esworthy et al., Environmental Protection Agency (EPA): Appropriations for FY2013, Congressional Research Service Report, at 2, 39, 41 (Sept. 6, 2012), available at http://www.fas.org/sgp/crs/misc/R42520.pdf [hereinafter Esworthy et al., Appropriations].

${ }^{86}$ Esworthy et al., Appropriations, supra note _, at 39.

${ }^{87}$ Pub. L. No. 96-510, 94 Stat. 2767 (1980).

${ }^{88}$ Pub. L. No. 99-499, 100 Stat. 1729 (1986).

${ }^{89}$ Pub. L. No. 98-616, 98 Stat. 3224 (1984).

${ }^{90}$ Pub. L. No. 100-4, 101 Stat. 60 (1987).

${ }^{91}$ Pub. L. No. 101-549, 104 Stat. 2468 (1990).

${ }^{92}$ EPA appropriations were $\$ 14,855.7$ million in FY 2009 (including emergency supplemental appropriations), $\$ 10,291.9$ million in FY 2010, \$8,682.1 million in FY 2011, \$8,449.4 in FY 2012, and \$8.3 billion in FY 2013. Esworthy et al., Appropriations, supra note _, at 41; U.S. House of Representatives, Committee on Appropriations, Appropriations Committee Releases Fiscal Year 2014 Interior and Environment Bill (July 22, 2013), http://appropriations.house.gov/news/documentsingle.aspx?DocumentID=343384. EPA's budget declined by 18\% from FY 2010 to FY2012, not counting the additional cuts caused by the sequestration in 2013. Coral Davenport, EPA Funding Reductions Have Kneecapped Environmental Enforcement, NAT’L J., Mar. 3, 2013.

${ }^{93}$ Because of a weak economy, President Obama proposed a further 3.5\% cut for the agency in fiscal year 2014. Gavin Broady, Obama Budget Would Force EPA To Tighten Its Belt, Law 360 (Apr. 10, 2013), http://www.law360.com/articles/431835/obama-budget-would-force-epa-to-tighten-its-belt. The House's Interior and Environment Appropriations budget bill, however, went much further, proposing to slash EPA's annual funding from $\$ 8.3$ billion to $\$ 5.5$ billion, a $34 \%$ reduction. U.S. House of Representatives, Committee on Appropriations, Appropriations Committee Releases Fiscal Year 2014 Interior and Environment Bill (July 22, 2013), http://appropriations.house.gov/news/documentsingle.aspx?DocumentID=343384. A press release issued by the House Appropriations Committee explained that "[t]he legislation reflects significant efforts to rein in the EPA - an agency that has been rife with governmental overreach, overspending on ineffective and unnecessary programs, and costly and questionable regulations." Id. See also Interior Appropriations Bill Limits EPA, Conservation Spending, Farm Futures (July 24, 2013), http://farmfutures.com/story-interior-appropriations-bill-limits-epa-conservation-
} 


\section{DRAFT - PLEASE DO NOT CITE OR DISTRIBUTE WITHOUT PERMISSION OF AUTHORS}

indirect way to weaken environmental regulations, likening the situation to "death by a thousand cuts." In comparison with recent budget declines, EPA's staffing has remained relatively constant since fiscal year 1992. EPA's peak workforce occurred in fiscal year 1999 and had declined by $5.5 \%$ by fiscal year $2012 .{ }^{95}$ EPA's declining resource pool presents it with difficult choices and has led it to consider significant cuts to some programs. ${ }^{96}$

The federal government has long provided financial assistance in the form of grants and loans to assist the states in performing their roles under the federal environmental statutes. Between fiscal years 2004 and 2012, annual appropriations for EPA categorical grants to assist states in implementing air, water, pesticide, and hazardous substance programs shrunk by about $\$ 85$ million. ${ }^{97}$ The Environmental Council of the States (ECOS) has expressed concern about reductions in federal funding for state environmental programs. ${ }^{98}$ The federal government is well aware of these concerns. ${ }^{99}$

spending-0-100631-spx_1 (quoting House Appropriations Chairman Hal Rogers) (“In addition, by holding back overly zealous and unnecessary environmental regulations, this bill can have a positive effect on our economy and will help encourage job growth.").

${ }^{94}$ Phil Taylor \& Jason Plautz, House proposed 'devastating' cuts to Interior, EPA accounts in fiscal 2014, ENV'T \& ENERGY DAILY, May 22, 2013 (quoting Frank O'Donnell of Clean Air Watch).

${ }^{95}$ Esworthy et al,, Appropriations, supra note _, at 20 (noting that there has been a general downward trend in FTEs since FY 2001); U.S. EPA, EPA's Budget and Spending, http://www2.epa.gov/planandbudget/budget. The House's fiscal year 2014 appropriations bill would have capped EPA employees at 1992 levels, which were essentially the same as the size of the workforce in 2012. U.S. House of Representatives, Committee on Appropriations, Appropriations Committee Releases Fiscal Year 2014 Interior and Environment Bill (July 22, 2013), http://appropriations.house.gov/news/documentsingle. aspx?DocumentID=343384. For graphic depictions of EPA's budget and full-time equivalent staffing levels over the years, see U.S. EPA FY 2014 Budget in Brief, at 13, available at $\mathrm{http} / / / \mathrm{www}$. radonleaders.org/sites/default/files/EPA_FY_2014.pdf.

The size of the workforce as a whole does not necessarily tell the complete story. The GAO has criticized EPA on the ground that it has "struggled for years to identify its human resource needs and to deploy its staff throughout the agency in a manner that would do the most good." U.S. Government Accountability Office, Environmental Protection Agency, Management Challenges and Budget Observations, GAO-12-149T, at 3 (2011). See also EPA Office of Inspector General, EPA Needs Better Agency-Wide Controls over Staff Resources, Report No. 11-P-0136 (Feb. 22, 2011), available at http://www.epa.gov/oig/reports/2011/20110222-11-P-0136.pdf; EPA Office of Inspector General, EPA Needs Workload Data to Better Justify Future Workforce Levels, Report No. 11-P0639 (Sept. 14, 2011), available at http://www.epa.gov/oig/reports/2011/201110914-11-P-0630.pdf.

${ }^{96}$ See EPA's Office of Enforcement and Compliance Assurance-Areas of Proposed Budget Adjustment for FY13 (available through a link provided in Joel Mintz, Cutting EPA's Enforcement Budget: What It Might Mean (Apr. 12, 2012), http://www.progressivereform.org/CPRBlog.cfm?idBlog=A6A2E941-98B3-8007-9CEEB42458BED78E). This source indicates that EPA's Office of Enforcement Compliance and Assurance (OECA) responded to the fiscal year 2013 budget by proposing "disinvestment" in areas such as acid rain control and reduced enforcement of a variety of regulatory programs.

${ }^{97}$ U.S. Government Accountability Office, Funding for 10 States' Programs Supported by Environmental Protection Agency Categorical Grants, GAO-13-504R, at 1 (May 6, 2013), http://www.gao.gov/products/gao-13$504 \mathrm{r}$ [hereinafter GAO, Funding for 10]. Appropriations for all EPA categorical grants decreased from a \$1.17 billion in fiscal year 2004 to $\$ 1.09$ billion in fiscal year 2012. Id. at 4 . For a graph plotting the amounts provided during this period, see $i d$. at 5 .

${ }^{98}$ Esworthy, How Are They Enforced?, supra note _, at 4 (citing ECOS, March 2008 Green Report: State Environmental Expenditures 2005-2008, March 12, 2008, available at http://www.ecos.org/section/states/spending).

${ }^{99}$ Esworthy, How Are They Enforced?, supra note _, at 4 (noting that the "the level of federal funding allocated to state and tribes to support effective enforcement of federal pollution control laws has . . . been a long-standing congressional concern"). It is often difficult to follow the money trail, given that "[d]etailed reporting of federal 


\section{DRAFT - PLEASE DO NOT CITE OR DISTRIBUTE WITHOUT PERMISSION OF AUTHORS}

The reductions in federal financial support for the states were especially problematic given that many states were cutting funds for their own environmental agencies and enforcement programs at the same time. ECOS concluded in 2009 and 2010 reports that reductions in state budgets for environmental enforcement threatened the viability of state enforcement programs. ${ }^{100}$ Between fiscal years 2011 and 2012, 24 states reduced funding for their environmental agencies, ${ }^{101}$ reflecting "an overall trend of decreasing budgets" for funding for state environmental agencies and, according to ECOS, "jeopardize[ing] states' ability to implement federally delegated programs and policies." 102 The CRS expressed concern about a mismatch between federal support provided and state needs, noting that " $\mathrm{t}]$ he adequacy of federal funds to assist states with these responsibilities has become a more contentious issue over time, as state revenues and spending generally have declined under recent economic conditions."103 The GAO similarly noted that "the importance of federal grants has increased, as some states have reduced their funding for certain environmental programs to address decreased state revenues and significant deficits in funding.",104

Some states responded to reduced funding for environmental programs by reducing staff levels and cutting outreach and technical assistance programs that can facilitate compliance. ${ }^{105}$ State environmental officials have reported to the GAO that resource constraints have required them to institute hiring freezes and reduce staff through attrition and layoffs. In addition, these officials reported that funding freezes or declines have affected their capacity to conduct activities such as permitting, inspections, and monitoring, all of which are critical to effective enforcement. $^{106}$

C. Changes in the Regulated Community and Regulator Responsibilities and Capacities: The Dynamic Character of Regulation

At the same time as resources available to agencies to enforce environmental laws have diminished, challenges facing enforcement officials have shifted as well. Among the factors that have made effective enforcement more daunting for some agencies and programs are an increase in the number of regulated entities; increases in regulations and mandates; implementation of

funding to states and states' funding contributions for pollution control enforcement/compliance activities is not readily available." Id. at 39.

${ }^{100}$ Esworthy, How Are They Enforced?, supra note _, at 4 (citing ECOS, Status of State Environmental Agency Budgets, 2009-2011, August 2010; ECOS, Impacts of Reductions in FY 2010 on State Environmental Agency Budgets, March 2010; ECOS, Funding Environmental Protection: State Budget Shortfalls and Ideas for Mitigating Them (June 2009), http://www.ecos.org/section/publications).

${ }^{101}$ ECOS Green Report - Status of State Environmental Agency Budgets, 2011-2013, at 1 (Sept. 2012), http://dl.dropboxusercontent.com/u/41680992/September\%202012\%20Green\%20Report.pdf. The 24 states with decreasing budgets experienced larger changes than the 25 states with increasing budgets, and the total decline in state environmental agency budgets from FY2011 to FY2012 averaged \$357,015 per state. Id.

${ }^{102}$ Id. at 2, 5 .

${ }^{103}$ Esworthy et al., Appropriations, supra note

${ }^{104} \mathrm{GAO}$, Funding for 10, supra note __, at 1 . , at 1 .

${ }^{105} I d$. at 4,9 . On the potential value of technical assistance and outreach by regulators, see Carol Foley \& Michael Elliott, Systems Design and the Promotion of Pollution Prevention: Building More Effective Technical Assistance Programs, 29 GA. L. REV. 449 (1995).

${ }^{106}$ GAO, Funding for 10, supra note __, at 4, 9-10. 


\section{DRAFT - PLEASE DO NOT CITE OR DISTRIBUTE WITHOUT PERMISSION OF AUTHORS}

programs that depend on making difficult causal connections between regulated activities and environmental harms; a movement in some contexts away from uniform regulatory treatment toward differentiated responsibility, which may arise under market-based or ambient-based approaches to regulation or other deviations from traditional regulatory tools; and a commitment to target significant violations whether by larger or smaller sources. ${ }^{107}$

For various reasons, contemporary government enforcement officials would face significant challenges in achieving effective enforcement of environmental laws even if the financial resources available for enforcement were not declining. In some instances, the size of the regulated community has grown. ${ }^{108}$ EPA has referred to the "breadth and expanding scope of the National Pollutant Discharge Elimination System (NPDES) regulated universe" as one of the challenges it faces in improving its enforcement performance. ${ }^{109}$ The number of point sources subject to CWA permitting requirements doubled over a recent ten-year period. ${ }^{110} \mathrm{~A}$ recent appellate court decision established, for example, that pesticide applications that allow chemical residues to enter surface water bodies may trigger regulation under that statute. ${ }^{111}$ Stormwater permitting has also increased the size of the regulated community. ${ }^{112}$ The resulting increase in permittees may present difficulties for federal and state regulators. ${ }^{113}$ In New York, regulated point sources increased by $63 \%$ between 1999 and 2012. ${ }^{114}$ In some of these contexts, it may be possible to reduce the burdens of regulating these sources through the creation of general permits, such as the ones available under both the CWA's dredge and fill ${ }^{115}$ and NPDES ${ }^{116}$ permit programs. Indeed, EPA has developed a general permit for pesticide and herbicide applications over surface waters. ${ }^{117}$ General permits undoubtedly reduce the resource

${ }^{107}$ Esworthy et al., Appropriations, supra note ___ at 4 (noting that the GAO had reported that funding for enforcement "had not kept pace with the increasing number of mandates and regulations, or with inflation").

${ }^{108}$ See, e.g., Bruce Harper, Trust But Verify: Innovation in Compliance Monitoring as a Response to the Privatization of Utilities in Developed Nations, 48 ADMIN. L. REV. 593, 614 (1996) ("An increase in the number of generators alone holds some potential to make environmental enforcement more difficult.").

${ }^{109}$ CWAP, supra note _, at 10.

${ }^{110}$ McAllister, supra note __, at 21-22. For further discussion of the expansion of the range of regulated sources under the Act, see infra notes _____ and accompanying text (discussion of EPA's 2009 CWAP).

${ }^{111}$ See National Cotton Council of Am. v. EPA, 553 F.3d 927 (6 ${ }^{\text {th }}$ Cir. 2009).

${ }^{112}$ See, e.g., U.S. EPA, Office of Inspector General, Limited Knowledge of the Universe of Regulated Entities Impedes EPA's Ability to Demonstrate Changes in Regulatory Compliance, Report No. 2005-P-00024, at 7 (Sept. 19, 2005), available at http://www.epa.gov/oig/reports/2005/20050919-2005-P-00024.pdf (identifying 45\% increase in universe of sources requiring stormwater permits under the CWA between 2001 and 2005). During the same period, the number of manufacturers covered by the Toxic Substances Control Act increased by 61\%. Id.

${ }^{113}$ See Kara Cook, Note, The Middle Ground of Pesticide Regulation: Why EPA Should Use a Watershed-Based Permitting Scheme in Its New Aquatic Pesticides Rule, 37 ECOLOGY L.Q. 451, 486 (2010) ("There are significant monitoring and enforcement challenges because of the sudden explosion in permitting applicants.").

${ }^{114}$ Environmental Advocates of New York, Turning a Blind Eye to Illegal Pollution: DEC's Failing Record on Enforcing Environmental Laws 8 (Sept. 2013), http://www.eany.org/our-work/reports/turning-blind-eye-illegalpollution-september-2013.

11533 U.S.C. $\$ 1344(\mathrm{e})$.

${ }^{116}$ See, e.g., 40 C.F.R. $\$ 122.28$ (a) (authorizing the use of general permits in lieu of individualized NPDES permits); California Sportfishing Prot. Alliance v. Chico Scrap Metal, Inc., 728 F.3d 868 (9 ${ }^{\text {th }}$ Cir. 2013) (involving California's Industrial Activities Storm Water General Permit). See general Jeffrey M. Gaba, Generally Illegal: NPDES General Permits Under the Clean Water Act, 31 HARV. ENVTL. L. REV. 409, 413 (2007).

${ }^{117}$ See, e.g., Final National Pollutant Discharge Elimination System (NPDES) Pesticide General Permit for Point Source Discharges From the Application of Pesticides, 76 Fed. Reg. 68,750 (Nov. 7, 2011). See also Determination 


\section{DRAFT - PLEASE DO NOT CITE OR DISTRIBUTE WITHOUT PERMISSION OF AUTHORS}

commitment a state must make at the permit approval stage, but agencies continue to have at least some ongoing responsibility for monitoring, oversight of reporting, and inspections. ${ }^{118}$ If agencies seek to reduce their administrative burdens by not only switching from source-specific to general permitting, but also by minimizing oversight of sources covered by general permits through reduced inspections or sporadic review of regulated entities' reports, one trade-off will be a decline in verifiability and accountability.

Efforts to enforce against private landowners, small businesses, or sectors of the business community (such as agriculture) that traditionally have not been enforcement targets also may pose new challenges, such as increased political opposition. Efforts to enforce wetlands permitting requirements under the CWA, for example, have generated intense political opposition and adverse publicity for the federal government. ${ }^{119}$

Changes in the nature of regulatory approaches also may exacerbate efforts to induce optimal levels of compliance. In recent years, for example, EPA has begun to shift its focus in implementing the CWA from enforcement of technology-based effluent limitations applicable to point sources to achieving state water quality standards through the implementation of ambient quality-based effluent limitations. ${ }^{120}$ Water quality standards are often expressed in terms of maximum ambient concentrations of pollutants in a surface water body. Implementation of such a standard requires a state environmental agency to establish a total maximum daily load (TMDL), which is an aggregate amount of pollution that may be discharged into a surface water body without resulting in concentrations of regulated pollutants in excess of those allowed by a state water quality standard. ${ }^{121}$ Establishing enforceable limits, monitoring whether allowed loadings (clearly enforceable or less so) are producing desired environmental results, and adapting to the findings are all resource-intensive enterprises. ${ }^{122}$ Determining whether a point source violated technology-based effluent limits, which are expressed as caps on end-of-pipe

of Endangered Species Status for Six West Texas Aquatic Invertebrates, 78 Fed. Reg. 41,228 (July 9, 2013) (describing Texas general permit program).

${ }^{118}$ See, e.g., 76 Fed. Reg. at 68,775 (listing among the Pesticide General Permit requirements the duties of applicators to monitor adverse incidents and document visual monitoring activities). General permits under the NPDES permit program may regulate one or more categories of discharges, provided that all sources within a category are subject to the same or similar monitoring requirements. 40 C.F.R. $§ 122.28(a)(2)(i i)(D)$.

${ }^{119}$ See, e.g., Felicity Barringer, Wetlands? What Wetlands?, http://green.blogs.nytimes.com/2011/04/20/wetlandswhat-wetlands/? r=0 (Apr. 20, 2011) (describing the background of Sackett v. EPA. 132 S. Ct. 1367 (2012), a case concerning CWA enforcement action to block construction of a single family home on property alleged to contain regulated wetlands, as an example of the view of libertarians and tea party members that EPA is the "embodiment of government run amok").

${ }^{120}$ See, e.g., GLICKSMAN ET AL., supra note___, at 614 (noting recent increase in the role of water quality standards and likely greater future reliance on those standards).

${ }^{121}$ Upper Blackstone Water Pollution Abatement Dist. v. EPA, 690 F.3d 9, 14 n.8 ( $1^{\text {st }}$ Cir. 2012) (quoting 33 U.S.C. $\S 1313(\mathrm{~d})(1)(\mathrm{C})$ ) ("A TMDL is a calculation of the maximum quantity of a pollutant that may be added to a water body from all sources without exceeding applicable water quality standards including 'a margin of safety which takes into account any lack of knowledge concerning the relationship between effluent limitations and water quality" ).

${ }^{122}$ It is difficult to overstate the complexity associated with the regulatory and non-regulatory enterprise of seeking to bring an impaired water up to a desired state. Cf. Sarah Birkeland, EPA's TMDL Program, 28 ECOLOGY L.Q. 297, 300 (2001) (referring to "the implementation and enforcement challenges faced by the EPA's TMDL program"). 


\section{DRAFT - PLEASE DO NOT CITE OR DISTRIBUTE WITHOUT PERMISSION OF AUTHORS}

discharges, is a relatively simple matter by comparison. Agency efforts to improve water quality by restoring and maintaining ecologically functioning ecosystems will likely create similar ripple effects on enforcement strategies. ${ }^{123}$ As regulatory challenges change, so do enforcement challenges, affecting optimal regulatory design of enforcement regimes, including agency gatekeeping of private enforcement.

Shifting from traditional regulatory techniques such as technology-based limits that apply to classes of regulated sources to market-based strategies that allow individual regulated entities to alter their responsibilities through inter-source transactions is another change in regulatory approach that is likely to create new enforcement challenges. ${ }^{124}$ Such a shift may make it more difficult to ascertain the nature and extent of enforceable duties of individual regulated entities. ${ }^{125}$ Some emissions trading markets have been exploited through the sale of credits for environmental improvements that would have occurred even without regulation, credits for which sellers have already been fully paid either in the same or another market, or credits that did not occur at all except on paper. ${ }^{126}$ Colorado noted that the burden on agencies to improve compliance may increase when requirements are tailored rather than consistent across an industry, not only because it will be more difficult for government inspectors to determine compliance, but also because "it may be more difficult to implement a self-certification program where individualized permits determine unique facility-specific compliance requirements."127

A final development that may increase the difficulty of enforcement for public and private enforcers is the effort to address significant environmental threats, even from sources that have not traditionally been the focus of agency enforcement attention, and to address sources that are emitting or discharging relatively small amounts, but whose violations may be cumulatively

\footnotetext{
${ }^{123}$ GLICKSMAN ET AL., supra note _, at 550 (describing new objectives geared toward restoration and maintenance of functioning ecosystems and toward control of nonpoint source pollution).

${ }^{124}$ U.S. environmental law has long been criticized for excessive reliance on traditional regulatory techniques such as uniform technology-based standards applicable to categories of regulated sources. The critics contend, among other things, that such approaches are inefficient because they fail to recognize differences among sources in the costs of controlling pollution. See, e.g., Bruce Ackerman \& Richard Stewart, Reforming Environmental Law, 37 STAN. L. REV. 1333 (1985). Policymakers have responded by incorporating market-based mechanisms such as tradeable permits into statutes such as the CAA. See, e.g., 42 U.S.C. $\$ 7651 b(b)$ (allowing purchase and sale of allowances for regulated utilities to emit sulfur dioxide under the Act's acid deposition control program).

${ }^{125}$ See, e.g., Dennis D. Hirsch, Protecting the Inner Environment: What Privacy Regulation Can Learn from Environmental Law, 41 GA. L. REV. 1, 39 (2006) ("The environmental experience shows that it is easier to keep track of a uniform technology than to police facility-specific pollution reduction strategies. Second generation strategies encourage differentiation. They accordingly offer less in the way of strict accountability and enforceability and open the door to bad-faith attempts to game the system.").

${ }^{126}$ See Philip Womble \& Martin Doyle, The Geography of Trading Ecosystem Services: A Case Study of Wetland and Stream Compensatory Mitigation Markets, 36 HARV. ENVTL. L. REV. 229, 291-92 (2012). For descriptions of these kinds of exploitations of environmental regulatory markets, see Richard Toshiyuki Drury et al., Pollution Trading and Environmental Injustice: Los Angeles' Failed Experiment in Air Quality Policy, 9 DUKE ENVTL. L. \& POL'Y F. 231 (1999); Elisabeth Rosenthal \& Andrew W. Lehren, Profits on Carbon Credits Drive Output of a Harmful Gas, N.Y. TIMES, Aug. 8, 2012, http://www.nytimes.com/2012/08/09/world/asia/incentive-to-slow-climatechange-drives-output-of-harmful-gases.html?pagewanted=all\&_r=0. See also Nicklas A. Akers, New Tools for Environmental Justice: Articulating a Net Health Effects Challenge to Emissions Trading Markets, 7 HASTINGS W.N.W. J. ENVTL. L. \& POL’Y 203 (2001).

${ }^{127}$ Schieffelin, supra note _, at 18.
} 


\section{DRAFT - PLEASE DO NOT CITE OR DISTRIBUTE WITHOUT PERMISSION OF AUTHORS}

significant. ${ }^{128}$ If enforcement initiatives target smaller sources, enforcers may have to initiate more actions and commit more resources to enforcement just to achieve the same level of environmental improvement through enhanced compliance. ${ }^{129}$ In addition, data relevant to compliance status may not be available to the same extent for small as for larger sources, making it more difficult to enforce against those sources, or at least more expensive as agencies must amass a data base that does not exist or is incomplete. ${ }^{130}$

Changes in regulatory challenges are not entirely in the direction of making government officials' jobs more difficult. There are also opportunities to promote compliance that may facilitate better performance. As Part III below indicates, these include improvements in monitoring capacity and enhancements in the capacity to manage and disseminate data and other information. Improved understanding of the mix of incentives that promote compliance also holds promise for improving the effectiveness of enforcement efforts. ${ }^{131}$

\section{A Brief Conclusion Concerning the Importance of Context to Regulatory Design}

Professor Engstrom's analysis focuses on rationalization and optimization of enforcement through coordination of private and public enforcement litigation. He identifies three kinds of problems posed by a regime that relies in part on private enforcement - what he refers to as zealousness, ${ }^{132}$ coordination, ${ }^{133}$ and democratic accountability challenges. ${ }^{134}$ He then asks whether vesting agencies with "gatekeeping" powers over private enforcement is a more promising approach to rationalizing public and private enforcement than litigation reforms of the kind that have been suggested or adopted in recent years. Legislation or judicial decisions that expand or narrow the circumstances in which prevailing parties in federal court litigation may recover attorneys' fees ${ }^{135}$ or that impose more rigorous pleading requirements on litigants ${ }^{136}$

\footnotetext{
${ }^{128}$ Cf. U.S. Environmental Protection Agency, Office of Inspector General, Limited Knowledge of the Universe of Regulated Entities Impedes EPA's Ability to Demonstrate Changes in Regulatory Compliance, Report No. 2005-P00024, at 14 (Sept. 19, 2005), available at http://www.epa.gov/oig/reports/2005/20050919-2005-P-00024.pdf [hereinafter OIG, Limited Knowledge] (reporting that, in multiple program areas, "OECA does not know the cumulative effects of pollution from small entities"). The OIG also reported that "some states and EPA regions have argued that RCRA small quantity generator facility inspections represent some of the most environmentally significant activities that regions and States conduct." Id. See also infra Part III.

${ }^{129}$ Cf. Bradley C. Karkkainen, Environmental Lawyering in the Age of Collaboration, 2002 WIS. L. REV. 555, 560 ("The remaining non-compliance cases often involve either smaller targets or more difficult problems of proof, making them costlier and riskier to litigate.").

${ }^{130}$ See, e.g., OIG, Limited Knowledge, supra note __, at 8 (discussing absence of reliable data on programs such as CAA regulation of minor stationary sources and regulation of small quantity generators under RCRA).

${ }^{131}$ See infra Part III.

${ }^{132}$ See supra note _ and accompanying text.

133 The coordination problem arises from "wasteful duplication of effort and socially costly overdeterrence by 'piggybacking' on public enforcement efforts and also on each other.” Engstrom, supra note 1, at __ [ms at 12]; supra note _ and accompanying text.

${ }^{134}$ Engstrom, supra note 1, at __ [ms at 7]; supra note _ and accompanying text.

${ }^{135}$ See, e.g., Buckhannon Bd. \& Care Home, Inc. v. West Virginia Dep't of Health \& Human Res., 532 U.S. 598 (2011) (rejecting catalyst theory for determining eligibility for fee-shifting provisions under the Equal Access to Justice Act). See generally Lucia A. Silecchia, The Catalyst Calamity: Post-Buckhannon Fee-Shifting in Environmental Litigation and a Proposal for Congressional Action, 29 CoLUM. J. ENVTL. L. 1 (2004); Catherine R. Albiston \& Laura Beth Nielsen, The Procedural Attack on Civil Rights: The Empirical Reality of Buckhannon for the Private Attorney General, 54 UCLA L. REV. 1087 (2007) (assessing the impact of Buckhannon).
} 


\section{DRAFT - PLEASE DO NOT CITE OR DISTRIBUTE WITHOUT PERMISSION OF AUTHORS}

certainly may affect the willingness of private litigants to bring enforcement actions. It is appropriate and important to compare the relative merits of these kinds of reforms and agency gatekeeping mechanisms of the kind Professor Engstrom analyzes, as Engstrom does.

In crafting an approach to rationalizing public and private enforcement, however, policymakers and students of the environmental regulatory process should be aware that developments throughout that process also significantly impact both public and private enforcement efforts, and therefore affect the value of a gatekeeping approach to addressing the critiques of private enforcement. As Part I above indicates, regulatory design efforts will benefit from understanding the relationships among five key characteristics of regulation, even in circumstances in which such efforts focus on a particular aspect of regulation, such as agency gatekeeping of private enforcement. Part II demonstrates that policymakers engaged in regulatory design also should consider a different set of contextual realities: the actual record of the agency involved, its capacity to fulfill statutory duties, and the dynamic character of the challenges facing agencies and the opportunities available to them in addressing those challenges. The overarching point is that regulatory design, even of public gatekeeping mechanisms for private enforcement, needs to be undertaken with a sophisticated understanding of the nature of the compliance promotion landscape that exists in a particular regulatory setting and of the changes in this landscape that are likely to occur over time.

III. Promoting Compliance throughout the Regulatory Process: A Review of EPA's Initiative to "Transform" Compliance and Enforcement under the Clean Water Act ${ }^{137}$

In this Part we return full circle to Professor Engstrom's original claim - that rationalization of the increasing volume of private enforcement litigation with government enforcement poses a central challenge in the modern regulatory state. We do so by exploring what degree of importance EPA seems to have attached to this challenge as it grapples with how best to reinvent its compliance promotion strategies under the CWA. It is not our objective to empirically evaluate Professor Engstrom's claim or to refute the relevance of the interplay between public and private enforcers to efforts to promote effective regulation. Instead, we simply seek to explore the extent to which one of the agencies on which Engstrom focuses, EPA, shares his perspective. As the description of EPA's recent compliance promotion efforts in this Part indicates, EPA does not appear to regard rationalization of public and private enforcement as either the essential challenge facing its compliance promotion efforts or as a priority to fostering increased compliance in the future. The agency's analysis of this feature of regulatory design is conspicuous by its absence. Rather, EPA's CWA strategies provide examples that support our claim that regulatory design in general, and design of compliance promotion mechanisms in particular, turn on a series of factors that reflect the multi-faceted, hybrid, and dynamic character of the regulatory process.

\footnotetext{
${ }^{136}$ See, e.g., Ashcroft v. Iqbal, 556 U.S. 662 (2009); Bell Altantic Corp. v. Twombly, 550 U.S. 544 (2007); Arthur R. Miller, From Conley to Twombly to Iqbal: A Double Play on the Federal Rules of Civil Procedure, 60 DUKE L.J. 1, 15-16 (2010) (assessing the impact of Iqbal and Twombly).

${ }^{137}$ Transform is EPA's word. See, e.g., Memorandum from Administrator Jackson on Improving Water Quality Transparency and Effective Enforcement of Clean Water Act Requirements (July 2, 2009), available at http://www.epa.gov/compliance/data/results/performance/cwa/jackson-ltr-cwa-enf.html.
} 


\section{DRAFT - PLEASE DO NOT CITE OR DISTRIBUTE WITHOUT PERMISSION OF AUTHORS}

Over the past five years EPA has acknowledged that its strategies for promoting compliance with the CWA, a statute that has been in place since $1972,{ }^{138}$ need improvement. ${ }^{139}$ In Professor Engstrom's parlance, EPA's statements reflect its awareness that its regulatory design of compliance efforts is not optimal. In a July 2009 Memorandum, EPA Administrator Lisa Jackson told the head of EPA's enforcement program, Cynthia Giles, that " $[\mathrm{w}] \mathrm{e}$ are . . . falling short [in] the effectiveness of our clean water enforcement programs," "140 and "the level of significant non-compliance with permitting requirements is unacceptably high . ..."141 Jackson accordingly directed Giles to develop an action plan to improve enforcement performance.

A few months later, in October 2009, EPA's Office of Enforcement and Compliance Assistance (OECA) issued the Agency's Clean Water Action Plan. ${ }^{142}$ Echoing the Administrator's concerns, OECA noted that "[v]iolations are . . too widespread, and enforcement too uneven." 143 OECA also emphasized the challenge presented by a substantially increased universe of regulated parties: "[ $t]$ he sheer magnitude of the expanding universe of the NPDES program itself, from roughly 100,000 . . . sources to nearly a million sources . . . presents challenges in how we regulate and enforce the laws. ..."144 EPA noted that the types of sources known to raise concerns has evolved as well: when EPA developed its enforcement policies, it focused primarily on the largest (or major) facilities with individual permits that are in significant noncompliance, but it found a rate of serious noncompliance at about 45 percent of smaller facilities. ${ }^{145}$ According to the CWAP, "[w]ithout complete and accurate data, it is hard to know how critical the noncompliance at smaller facilities is to water quality. It is likely that these smaller but more numerous sources are of critical concern, especially where there are

\footnotetext{
${ }^{138}$ Pub. L. No. 92-500, 86 Stat. 816 (1972).

${ }^{139}$ Concerns pre-dated this latest EPA call for improvements. See Markell, Deterrence-Based Enforcement, supra note __; RECHTSHAFFEN \& MARKELL, supra note __. Generally, the CWA requires thousands of entities across the country to obtain individual or general permits that allow them to discharge water pollution. Compliance-related efforts have focused on optimizing compliance with these permit requirements. One of the primary strategies EPA has used is enforcement litigation against parties operating in "significant non-compliance" with permit obligations. See, e.g., EPA Office of Compliance and Enforcement Assurance, EPA's Interim Significant Noncompliance Policy for Clean Water Act Violations Associated with CSOs, SSOs, CAFOs, and Storm Water Point Sources (Oct. 2007), available at http://www.epa.gov/compliance/resources/policies/state/srf/sncpolicy-attach1.pdf.

${ }^{140}$ Memorandum from Administrator Jackson on Improving Water Quality Transparency and Effective Enforcement of Clean Water Act Requirements (July 2, 2009), available at http://www.epa.gov/compliance/data/results/performance/cwa/jackson-ltr-cwa-enf.html. See also CWAP, supra note _, at 2 ("Unfortunately, data shows us that we are not getting the compliance envisioned by our laws to protect clean water."); id. at 3 ("State enforcement response to serious violations, whether at large or smaller facilities, is not what it should be."). The memo adds that: 1) traditionally EPA has focused more on large, "major" facilities than others; 2) it has not even required states to submit data about smaller facilities to EPA; and 3) therefore, that whereas EPA does not know the percentage of smaller sources nationally that are in significant compliance, compared to the rate for major facilities. But for the 28 states, 4 territories, and D.C., which have provided some of these data, the rate of significant noncompliance at smaller facilities is around 45 percent, nearly twice the rate for major facilities. The Plan concludes that "EPA and states need consistent, national data to be able to formulate appropriate strategies for ensuring compliance from these facilities, and to target enforcement resources to the sources most affecting water quality." Id. at 3.

${ }^{141}$ Memorandum from Administrator Jackson, supra note

${ }^{142}$ CWAP, supra note

${ }^{143}$ Id. at Executive Summary.

${ }^{144} I d$. at 1, 12 (noting that EPA's CWA-based permitting and enforcement program has “expanded its regulated universe more than tenfold").

145 Id. at 3 .
} 


\section{DRAFT - PLEASE DO NOT CITE OR DISTRIBUTE WITHOUT PERMISSION OF AUTHORS}

clusters of permitted facilities around impaired waters."146 OECA stated that EPA needed to "revamp" enforcement to meet these challenges. ${ }^{147}$ Based on its own assessment, and considerable outreach, ${ }^{148}$ OECA identified "three major themes for action" to improve compliance, noting that its outreach efforts engendered a "surprising coalescence" around these themes. ${ }^{149}$ The three themes, discussed below, are the need to focus on the most significant threats, to strengthen EPA-state partnerships and improve the performance of each partner, and to improve accountability and transparency.

\section{A. The Need to Focus Enforcement on the Most Significant Threats}

The first theme for action identified in the CWAP is the need to focus enforcement on the "biggest threats to water quality and public health." 150 This strategy (or approach to regulatory design) might seem obvious. But as EPA points out, an unintended consequence of EPA's traditional regulatory design, which was to focus on the biggest facilities (known in EPA parlance as "majors") was that EPA paid little attention to the "full range of the NPDES regulated universe," 151 including "non-major" sources whose discharges caused significant environmental problems.

EPA identified a range of "new approaches and new tools" to address its proposed shift in enforcement strategy. ${ }^{152}$ For example, EPA noted its need to improve its data management in order to be able to understand the relationship between compliance problems and their impacts

\footnotetext{
${ }^{146} I d$. Professor Dick Pierce recognized decades ago that "[s]mall firms do not produce disproportionate quantities of social 'goods.' They do produce massively disproportionate quantities of social 'bads." Richard J. Pierce, Small Is Not Beautiful: The Case Against Special Regulatory Treatment of Small Firms, 50 ADMIN. L. REV. 537,539 (1986). See also id. at 557 ("small firms account for a disproportionate quantity of the social bads that we attempt to reduce through regulation."); $i d$. at 559 ("Small firms also are responsible for a massively disproportionate share of water and air pollution.”). Professor Pierce was addressing small firms, not necessarily small facilities, but EPA's assessment in the CWAP indicates that similar conclusions may apply to small sources, especially when assessing the aggregate impacts of their discharges.

${ }^{147} I d$. at Executive Summary, 5. EPA noted that some water quality problems are caused by sources not currently being regulated. Id. at 6 . Our focus, like Prof. Engstrom's, is on optimal regulatory design in the compliance arena; we do not address the need to revisit the scope of underlying regulatory schemes (such as by covering nonpoint sources currently exempt from most CWA regulation).

${ }^{148}$ Outreach included solicitation of input from academics, industry, and environmental and environmental justice NGOs, among others. Id. at 5.

${ }^{149}$ Id. at 6. Since issuing its Plan in 2009, EPA has followed through in various ways. See, e.g., Memorandum from Cynthia Giles \& Peter Silva on Interim Guidance to Strengthen Performance in the NPDES Program (June 22, 2010), available at http://www2.epa.gov/enforcement/interim-guidance-strengthen-performance-npdes-program. See also U.S. ENVIRONMENTAL PROTECTION AGENCY, OFFICE OF ENFORCEMENT AND COMPLIANCE ASSURANCE, CWA ACTION PLAN IMPLEMENTATION PRIORITIES: CHANGES TO IMPROVE WATER QUALITY, INCREASE COMPLIANCE AND EXPAND TRANSPARENCY (2011) [hereinafter INCREASED COMPLIANCE], available at http://www.epa.gov/compliance/resources/publications/civil/programs/cwa/actionplan-implpriorities.pdf.

${ }^{150}$ CWAP, supra note , at 6.

${ }^{151} \mathrm{Id}$.

${ }^{152} I d$. at 7. EPA discussed several of the new tools it has developed in a 2011 memorandum, INCREASED COMPLIANCE, supra note
} 


\section{DRAFT - PLEASE DO NOT CITE OR DISTRIBUTE WITHOUT PERMISSION OF AUTHORS}

on water quality. ${ }^{153}$ Data about water quality, permit limits, and permit violations "reside in different systems and have not been routinely used together to help target serious problems." "154 Second, EPA highlighted the importance of improving tools across the spectrum of regulation, indicating that while responses might include enforcement actions, addressing water quality concerns also might require fixing problematic regulations and improving operating permits. ${ }^{155}$ Third, the agency focused on integrating its "state partners" better in its discussion about options for addressing the "biggest threats.", 156

In short, EPA's strategy in addressing the first significant deficiency it identified in extant compliance promotion efforts involved several of the key elements of a conceptual framework for regulatory design that we introduced in the introduction to this Essay. First, EPA's strategy acknowledged the inter-related character of the regulatory process and the need to consider actions, including improvements in its regulations, the operation of the CWA's permitting regime, and its management of data throughout the process to improve compliance (our first characteristic). Second, EPA's goal of better integrating states into its enforcement initiatives reflects the hybrid nature of the regulatory process. Third, the agency's decision to refocus its efforts was based on the "reality check" that historically it was giving insufficient attention to significant violators by focusing on a small subset of the regulated party universe. Fourth, EPA's commitment to take advantage of improved technology to make "timely, easily accessible and understandable information available to the public concerning violations/violators, actions EPA and states are taking to address them, and the effects of our actions on water quality"157 relates to our first characteristic (inter-relatedness) and our fourth (dynamism).

B. Strengthening the State/EPA Partnership and the Performance of Each

The second "major theme for action" that EPA identified in its CWAP, not entirely distinct from the first, is the need to strengthen the performance of the states, the key implementers of the CWA. States play an indispensable implementation role within cooperative federalism systems, the governance model (regulatory design) Congress adopted in the major environmental laws. ${ }^{158}$ The Plan notes that reviews of state performance have identified widespread deficiencies, and EPA has identified the importance of federal oversight to motivate improvements in such performance:

\footnotetext{
${ }^{153} I d$. (noting that "[o]nce we have identified significant point source violations across the spectrum of regulated facilities that adversely affect water quality, we will work with state programs to commence appropriate federal and state civil and criminal enforcement actions.")

${ }^{154} \mathrm{Id}$.

${ }^{155} \mathrm{Id}$.

${ }^{156} I d$. For example, OECA has recently indicated that it is receptive to allowing states to scale back inspections and monitoring at large facilities to free up resources for more intensive scrutiny at smaller facilities, at which compliance rates are lower. Reflecting the complexity of the cooperative federalism approach, however, another recent report indicates that while states are ready to refocus their efforts, some of EPA's regional offices have expressed less willingness to go along with shifting enforcement-related resources from large facilities to higher priority smaller ones. See EPA Plan for Flexible Compliance Monitoring May Fall Short of States' Goal, ENVTL. POLICY ALERT/INSIDE EPA (Oct. 2, 2013), at 33 (noting that "some state officials said EPA regional officials do not appear open to ... scaling back resource-intensive inspections at large facilities with typically good compliance records in exchange for more inspections at smaller, less-reviewed plants").

${ }^{157}$ CWAP, supra note _, at 7.

${ }^{158}$ Forty-six states are currently authorized to implement the CWA NPDES program. Id. at 8.
} 


\section{DRAFT - PLEASE DO NOT CITE OR DISTRIBUTE WITHOUT PERMISSION OF AUTHORS}

[The many reviews of state permitting and enforcement performance] have identified a lack of consistency in performance across states and highlighted common issues such as permit backlogs, failure to identify significant noncompliance, or to take timely and appropriate enforcement. EPA must consistently respond to these issues and press states and ourselves to make the appropriate improvements in order to achieve equitable protection to the public, a level playing field for competing businesses, and fairness across states in how our environmental laws are enforced. ${ }^{159}$

This EPA priority is consistent with Professor Engstrom's insight that "rationalization" of the work and responsibilities of different actors is a central challenge of governance, but EPA's focus is on a different piece of the hybrid governance conundrum, and it is consistent with our point (the second of our key conceptual elements of regulatory design) that design efforts must be cognizant of the roles of all stakeholders in a hybrid regulatory process. Particularly in the cooperative federalism context built into the environmental statutes, it is unsurprising that EPA would make rationalization of its relationship with the states a top priority. ${ }^{160}$ As we have pointed out elsewhere, ${ }^{161}$ EPA exercises ex ante gatekeeping and ex post oversight of state enforcement and one of its long-standing challenges is to rationalize its relationship with the states. The availability of citizen suits complicates this rationalization challenge because such suits make it possible for three enforcers with different interests and capacities to be concerned about particular alleged violators. EPA, in short, ideally will consider private party, state, and federal capacities and pathologies in pursuing rationalization of the enforcement action among all three sets of actors. Professor Engstrom builds on past work addressing pieces of this challenge. ${ }^{162}$ Hybrid governance challenges and opportunities need to be addressed through better integration of state actors as well as NGOs throughout the regulatory process.

EPA's focus in the CWAP on rationalizing federal and state enforcement efforts reflects not only our point about the importance of hybrid governance considerations to regulatory

\footnotetext{
${ }^{159}$ Id. These concerns are not new. One observer, for example, rendered the following assessment 20 years ago: "Enforcement of environmental laws by the EPA and the authorized states, however, has largely been an uncoordinated, piecemeal effort. Individual EPA offices and their state counterparts have generally functioned independently. ... . The insularity of the EPA's separate offices and their state-level counterparts has at times resulted in duplicate and conflicting actions." Peter J. Fontaine, EPA's Multimideia Enforcement Strategy: The Struggle to Close the Environmental Compliance Circle, 18 CoLUM. J. ENVTL. L. 31, 34 (1993). For book-length treatment, see RECHTSHAFFEN \& MARKELl, supra note _. See also Markell, Slack, supra note __, at 8-10. For a recent review of an innovative process intended to empower citizens to raise such concerns administratively, see Emily Hammond \& David L. Markell, Administrative Proxies for Judicial Review: Building Legitimacy from the Inside-Out, 37 HARV. ENVTL. L. REV. 313(2013).

${ }^{160}$ See, e.g., Hari Osofsky, Diagonal Federalism and Climate Change Implications for the Obama Administration, 62 ALA. L. REV. 237, 285 (2011) (discussing cooperative federalism's potential to “create coordinated multiscalar action in which each actor provides its unique contribution"); Robert L. Fischman, Cooperative Federalism and Natural Resources Law, 14 N.Y.U. ENVTL. L.J. 179, 195 (2005) (referring to coordination between federal and state entities as "an irreducible aspect" of cooperative federalism); Philip J. Weiser, Federal Common Law, Cooperative Federalism, and the Enforcement of the Telecom Act, 76 N.Y.U. L. REV. 1692 (2001).

${ }^{161}$ Hammond \& Markell, supra note _ , at

${ }^{162}$ See, e.g., Jeffrey G. Miller, Theme and Variations in Statutory Preclusions Against Successive Environmental Enforcement Actions by EPA and Citizens, Part One: Statutory Bars and in Citizen Suit Provisions, 28 HARV. ENVTL. L. REV. 401 (2004); Jeffrey G. Miller, Theme and Variations in Statutory Preclusions Against Successive Environmental Enforcement Actions by EPA and Citizens, Part Two: Statutory Preclusions on EPA Enforcement, 29 HARV. ENVTL. L. REV. 1 (2005).
} 


\section{DRAFT - PLEASE DO NOT CITE OR DISTRIBUTE WITHOUT PERMISSION OF AUTHORS}

design, but other conceptual elements as well. EPA's identification of deficiencies in state performance at different stages of the regulatory process relates to our first element (the interrelationship of the different phases of the regulatory process). The agency's apparent decision to regard rationalization of federal and state enforcement as a higher priority than the rationalization of public and private enforcement that is the subject of Professor Engstrom's analysis relates to our fifth element (salience). ${ }^{163}$ To the extent that EPA regards past state enforcement efforts as ineffective, the second element of its CWAP strategy also implicates our "reality check" feature. Thus, EPA's goal of strengthening state performance bears on at least four of the elements of our conceptual framework for improving regulatory design.

\section{Improving Accountability and Transparency}

The third theme around which EPA and its stakeholders coalesced in the CWAP is the need to improve accountability and transparency. ${ }^{164}$ Related to the prior two themes, EPA acknowledged that it "lacks nationally consistent and complete information on the facilities, permits, pollutant discharges and compliance status of most NPDES-regulated facilities."165 Data problems exist across the board, including "data quality, accuracy, and completeness."166 Inevitably, the infrastructure problem these data gaps represent "affects the ability of EPA and states to identify violations . . . , connect violations to water quality impacts, and to share information with the public." "167 The Plan notes that the "breadth and expanding scope of the NPDES regulated universe" heightens the challenge of responding to the long-standing data problems. ${ }^{168}$ The CWAP indicates that, because of the size of the challenge and the costs involved (it would cost over \$100 million/year to generate the data EPA would like to have), EPA will explore new ways to fill these data gaps, including using technological advances. ${ }^{169}$

Innovative information-gathering technologies may facilitate the ability of regulators and potential private enforcers to identify regulatory violations. Geographic information systems, global positioning satellite technologies, and remote sensing devices already support the investigation and enforcement of environmental laws in ways that were not previously possible. ${ }^{170}$ Some of this technology is available to the public at little or no cost from the U.S. Geological Survey or state governments. Data such as aerial photography that can help identify past environmental conditions, violations, and violators may not be available elsewhere. ${ }^{171}$ As

\footnotetext{
163 See supra note __ and accompanying text.

${ }^{164}$ Thus, this theme bears on the third and fifth features of effective regulation we describe above. See supra Part I.

${ }^{165}$ CWAP, supra note , at 10 .

${ }^{166} \mathrm{Id}$.

${ }^{167} \mathrm{Id}$.

${ }^{168} \mathrm{Id}$.

${ }^{169}$ See 78 Fed. Reg. 76,005 (July 30, 2013), for the rulemaking EPA has proposed to require electronic reporting that the agency hopes will address quality, accuracy, completeness, and timeliness concerns associated with its data.

${ }^{170}$ See Peter Stokely, Using Aerial Photography, Geospatial Data, and GIS to Support the Enforcement of Environmental Statutes, 28-Summer NAT. RESOURCES \& ENV'T 38 (2013). Remote sensing is "the science and art of obtaining information about an object, area, or phenomenon through the analysis of data acquired by a device not in contact with the object, area, or phenomenon under investigation." Kenneth J. Markowitz, Legal Challenges and Market Rewards to the Use and Acceptance of Remote Sensing and Digital Information as Evidence, 12 DUKE ENVTL. L. \& POL'Y F. 219, 221 (2002).

${ }^{171}$ Stokely, supra note___, at 39 ("In many instances, historical aerial photography is the only data source about past environmental conditions and can help catch a polluter or identify a past pollution source.”); id. at 42 (asserting that
} 


\section{DRAFT - PLEASE DO NOT CITE OR DISTRIBUTE WITHOUT PERMISSION OF AUTHORS}

Professor Dan Esty has noted, "[t]echnological advances in data collection, analysis, and dissemination have the potential to revolutionize our response to environmental problems." 172 Thus, for example:

Breakthroughs in nanotechnologies and small-scale sensors ... have begun to provide a vastly improved ability to detect and measure pollutants at a fine-grained level. Similarly, remote sensing from satellites in space and other new macroscale sensor technologies appear poised to provide on-the-ground monitoring of environmental conditions from anywhere, at any time, at increasingly low cost. We thus are approaching the day when virtually all emissions will be susceptible to tagging, tracking, and measurement at relatively low cost.

Air emissions already are being tracked with a degree of sophistication that was unimaginable just a few years ago. Gaussian plume analysis now permits regulators to plot the drift of air pollutants with increasing precision. Advances in meteorological modeling have further enhanced our ability to understand the sources and "receptors" of air pollution. Similar gains are being made in tracing pollutants as they flow through watersheds and hydrological systems. ${ }^{173}$

Esty adds that, "[s]imply put, these gains in data management, analysis, and retrieval make possible a more empirical and quantitative approach to environmental protection." ${ }^{174}$ These data can facilitate efforts to induce higher compliance levels by motivating regulated parties to comply without the need for enforcement action and by strengthening deterrence by providing information that facilitates proof that violations have occurred. ${ }^{175}$

The dynamic nature of changes in information technology means that the economics, feasibility, and chances for success of enforcement will not remain static, likely resulting in a shift in the balance of public and private enforcement over time. As monitoring technology improves, for example, it may become cheaper for NGOs to acquire the data they need to support private enforcement actions. Professor Engstrom regards as "overblown and indeterminate" the zealousness critique of private enforcement, which identifies as costs of private enforcement overexpenditure of social resources and costly overdeterrence. ${ }^{176}$ If this critique is at all accurate, however, improvements in monitoring technology may exacerbate the "overzealousness" of private enforcement by reducing the costs of the fact-gathering needed to support allegations of noncompliance.

\footnotetext{
"aerial photograph and mapping, particularly historical aerial photography and maps, can be also key pieces to the environmental enforcement puzzle"). Cf. Katrina Fischer Kuh, Personal Environmental Information: The Promise and Perils of the Emerging Capacity to Identify Individual Environmental Harms, 65 VAND. L. REV. 1565, 1592-93 (2012) (describing utility of GIS data about environmental conditions to urban planners and policymakers).

172 Daniel C. Esty, Environmental Protection in the Information Age, 79 N.Y.U. L. Rev. 115, 156-57 (2004),

${ }^{173} \mathrm{Id}$.

${ }^{174} I d$. at 158 . The use of better monitoring technology is a critical element of EPA's Next Generation Compliance approach, including use of "field technologies to get real-time information on ambient conditions and compliance." EPA, Improving Oversight, supra note _, at 7.

${ }_{175}$ Markowitz, supra note __, at 228-29.

${ }^{176}$ Engstrom, supra note 1, at __ [ms at 10-11].
} 


\section{DRAFT - PLEASE DO NOT CITE OR DISTRIBUTE WITHOUT PERMISSION OF AUTHORS}

Similarly, improvements in monitoring technology also may affect gatekeeping design decisions animated by the legislative fidelity critique of private enforcement that Professor Engstrom references, which is based on the political accountability of public but not private enforcers. The lack of accountability of private enforcers creates a risk of legislative drift if private enforcers "develop and press novel applications of legal mandates that public enforcers, exercising sound prosecutorial discretion, would forgo as inconsistent with original legislative intent. Relentless pursuit of profit thus yields a form of statutory drift and mission creep as private enforcers drive law enforcement efforts in new and democratically unaccountable directions." 177 One counter to this argument, noted by Engstrom, is that Congress took into account and implicitly endorsed this kind of "zealous" enforcement by private litigants when it created citizen suit provisions, thereby "conferring democratic legitimacy, though at a higher level of generality," on such enforcement pursuits. ${ }^{178}$ To the extent that the legislative drift critique has any cogency, however, changes in the nature of monitoring technology, and therefore in the implementation of environmental statutes, can spur suits that would not otherwise have been brought, adding to the chances that regulatory policy will be set in the context of private litigation in ways which Congress or the agency deem unwise. ${ }^{179}$

Another possible result of better monitoring information that may affect gatekeeping design considerations involves the possibility that improvements in monitoring data (to the extent they increase the chance of successful prosecution or reduce the cost of pursuing cases) may induce government to initiate enforcement action in marginal cases in which it previously would not have been cost-justified. This might reduce the need for private enforcement. Similarly, better monitoring information may motivate regulated parties not to violate the law in the first place, thereby influencing the universe of cases that deserve formal enforcement, an important consideration in gatekeeping regime design.

Invoking the experience with the Toxics Release Inventory (TRI) program, the CWAP touts the promise of transparency as a tool to improve compliance. ${ }^{180}$ EPA suggests that public

\footnotetext{
${ }^{177}$ Engstrom, supra note 1, at _ _ [ms at 15]. This argument has gotten traction with some Supreme Court justices. See, e.g., Friends of the Earth, Inc. v. Laidlaw Envtl. Serv. (TOC), Inc., 528 U.S. 167, 209 (2000) (Scalia, J. dissenting) (“A Clean Water Act plaintiff pursuing civil penalties acts as a self-appointed mini-EPA.”).

${ }^{178}$ Engstrom, supra note 1, at _ [ [ms at 15]. Because citizen suits are expressly authorized by statutes such as the CWA, and the statutes specify who can sue and under what circumstances, private individuals and NGOs that qualify to bring such suits are not self-appointed at all.

${ }_{179}$ As Engstrom points out, judges are participants in litigation and may have their own policy preferences, which exacerbate the risks of drift from legislative purposes. Engstrom, supra note 1, at __ [ms at 15] (quoting Frederick Schauer \& Richard Zeckhauer, The Trouble with Cases, in REgUlATION VERSUS LITIGATION: PERSPECTIVES FROM ECONOMICS AND LAW 45, 47 (Daniel P. Kessler ed., 2011)) ("[T] he policy that emerges from litigation [will] be systematically based on an imperfect picture of the terrain that the policy is designed to regulate.").

${ }^{180}$ The TRI program was created by $\S 313$ of the Emergency Planning and Community Right-to-Know Act, Pub. L. No. 99-499, 100 Stat. 1729, 1741 (1986) (codified at 42 U.S.C. $§ 11023$ ). It requires facilities that manufacture, process, or use toxic chemicals listed by EPA in amounts that exceed designated threshold quantities to complete and submit to EPA and state officials toxic chemical release forms. The submitted information is made available to inform persons about toxic chemical releases, assist agencies and researchers in conducting research and data gathering, and aid in the development of appropriate regulations. 42 U.S.C. $§ 11023(\mathrm{~h})$. The TRI program may be less than an ideal model for improving transparency and verifiability. See, e.g., M.B. Pell, Ryan McNeill \& Selam Genrakidan, Exclusive: U.S. system for flagging hazardous chemicals is widely flawed, REUTERS, July 8, 2013, http://mobile.reuters.com/article/environmentNews/idUSBRE9670K720130708 (describing investigation concluding that the TRI reporting program is plagued by scant oversight by EPA and the states and by incomplete or
} 


\section{DRAFT - PLEASE DO NOT CITE OR DISTRIBUTE WITHOUT PERMISSION OF AUTHORS}

pressure and greater regulated party self-awareness can both motivate better performance. For our purposes, the key point is that, in identifying strategies to improve compliance, EPA is looking well beyond ex post enforcement and considering a range of tools throughout the regulatory process (our first characteristic). In doing so, it is by no means dismissing the value of traditional enforcement; it is simply calling for use of additional tools to address compliance challenges, a position we have taken in previous work ${ }^{181}$ and which academic literatures support. ${ }^{182}$ According to EPA, "[t]ransparency is not a replacement for regulatory enforcement, but can be an effective driver for improved performance and accountability." 183 This third significant theme of EPA's reinvention effort reflects EPA's view that rationalization (to use Professor Engstrom's term) of ex post enforcement by public and private actors is only part of the answer to altering sub-optimal regulatory design to enhance compliance. The CWAP's third theme also illustrates how considerations relating to hybrid governance and the dynamic nature of the regulatory environment can affect regulatory design choices, and that these aspects of regulatory design may affect key characteristics of effective regulation, including implementability, verifiability, the creation of appropriate compliance incentives, and regulatory legitimacy. The point is that optimal regulatory design of gatekeeping structures will shift over time as technology advances, government capacity evolves in other ways, ${ }^{184}$ and more is learned about what works and what doesn't to motivate regulated party compliance. Decisions about the design of such structures should be made with the dynamic character of optimality in mind.

\section{Conclusion}

In Agencies as Litigation Gatekeepers, Professor David Engstrom tackles the challenge of regulatory design across the agency landscape with a particular focus on the rationalization of regulatory enforcement by government and private enforcers. Engstrom, appropriately in our view, suggests that enforcement is not likely to be either entirely public or private; instead, the design challenge is to consider how best to rationalize enforcement actions by both sets of actors. Further, he suggests that in addition to using litigation rules to achieve an optimal form of rationalization it is possible to design agency gatekeeping of private enforcement to advance this goal. Engstrom offers a continuum of government gatekeeping design options from more to less interventionist.

Our purpose in this Essay is to highlight the importance that context plays in regulatory design, and based on EPA's experience, to suggest our own five-part conceptual framework for how to approach optimal regulatory design. First, efforts to advance optimal regulatory design need to consider the fundamentally inter-related character of the regulatory process. We offer a taxonomy of the regulatory process that highlights key features of that process and provide illustrations of the types of interconnections that require attention as part of optimal regulatory

\footnotetext{
inaccurate reporting by regulated entities, and charging that EPA and most states "make no effort to verify the [reported] data").

${ }^{181}$ See Markell, Deterrence-Based Enforcement, supra note _. Cf. Robert L. Glicksman \& Dietrich H. Earnhart, The Relative Efficacy of Coercive and Cooperative Enforcement Approaches to Water Pollution Control, in NEXT GENERATION COMPLiAnCE (L. Paddock \& J. Wentz, eds., Envtl Law Inst., forthcoming) [hereinafter NEXT GENERATION COMPLIANCE] (discussing deterrence-based, cooperative, and "responsive" regulatory approaches).

${ }^{182}$ See, e.g., GOVERNANCE FOR THE ENVIRONMENT, supra note _; NEXT GENERATION COMPLIANCE, supra note

${ }^{183}$ CWAP, supra note __, at 10.

${ }^{184}$ See Grabowsky, supra note 65.
} 


\section{DRAFT - PLEASE DO NOT CITE OR DISTRIBUTE WITHOUT PERMISSION OF AUTHORS}

design efforts. ${ }^{185}$ Second, efforts to achieve optimal regulatory design should be mindful of the hybrid character of contemporary governance. Even if the goal is to rationalize agency gatekeeping of private enforcement, design should take into account how best to engage all stakeholders in different stages of the regulatory process, not just public officials and NGO litigants during the ex post stage of enforcement litigation. Third, we suggest that optimal regulatory design, whether of agency gatekeeping of private enforcement or otherwise, requires what we term a "reality check" contextual feature. It is critical to assess the agency's (here EPA's) actual performance in conducting enforcement, the challenges it faces, and available opportunities to improve performance. Fourth, we suggest regulatory designers must consider the degree of dynamism - the likelihood that capabilities and interests of different key actors throughout the entire regulatory enterprise will change over time in ways that impact the effectiveness of regulation. Finally, we suggest that in a world of limited resources regulatory designers should consider the salience of revisiting the design of particular phases of the regulatory process and prioritize efforts to redesign regulatory components accordingly.

We also provide a set of gauges for effective regulation that may be useful in assessing regulatory design options that emerge from this interconnected framework, including clarity, workability, verifiability, the creation of appropriate incentives for regulated entities, and legitimacy. Finally, in response to Professor Engstrom's call for greater rationalization of public and private enforcement, we broaden the focus to regulatory design of optimal compliance structures generally, including but not limited to integration of public and private enforcement, by sketching out the compliance challenges currently facing EPA and EPA's attempt to address these challenges by engaging in efforts to enhance compliance under a key environmental statute, the CWA. Our discussion of these challenges and potential solutions illustrates the value of taking the multi-faceted approach to regulatory design we recommend and the potential our approach has for more effectively fostering statutory compliance.

At its heart, a strong pragmatic orientation grounds this Essay. We have developed what we hope is a conceptual framework for improving regulatory design that offers a somewhat different, yet complementary lens for thinking about regulatory design than the approach by Professor Engstrom that has prompted our assessment.

\footnotetext{
${ }^{185}$ This interconnection is important in multiple ways. For example, design and implementation of other stages of the regulatory process influence optimal design and implementation of the gatekeeping element that Professor Engstrom highlights. In addition, design and implementation of this gatekeeping element may affect design and implementation of other aspects of the regulatory process.
} 